\title{
Cytokine-dependent and cytokine-independent roles for Mcl-1: genetic evidence for multiple mechanisms by which Mcl-1 promotes survival in primary T lymphocytes
}

\author{
A Dunkle ${ }^{1}$, I Dzhagalov ${ }^{1}$ and $Y-W \mathrm{He}^{*, 1}$
}

Myeloid cell leukemia sequence-1 (Mcl-1) is a critical anti-apoptotic factor in T lymphocytes. However, in spite of the many pro-apoptotic proteins with proposed binding to Mcl-1, the specific interactions by which Mcl-1 regulates primary T-cell survival under different conditions have not been fully explored. Further, how different trophic cytokines modulate the specific role(s) of $\mathrm{Mcl}-1$ is unknown. Here, we use genetic mouse models to dissect the roles of Mcl-1 in primary T lymphocytes. Using the inducible Mcl-1-floxed estrogen receptor-Cre fusion protein (Mcl-1/ffERCre) deletion system in combination with genetic modification of other B-cell lymphoma 2 (Bcl-2) family members, we show that loss of pro-apoptotic Bcl-2 homologous antagonist/killer (Bak) rescues the survival of Mcl-1-deficient T cells in the presence of IL-7. Without IL-7, the survival of Mcl-1-deficient cells cannot be rescued by loss of Bak, but is partially rescued by overexpression of $\mathrm{Bcl}-2$ or loss of Bcl-2-interacting mediator of cell death (Bim). Thus, Mcl-1 and Bcl-2 have a shared role, the inhibition of Bim, in promoting T-cell survival during cytokine withdrawal. Finally, we show that other common gamma-chain $(\gamma c)$ cytokines differentially modulate the roles of Mcl-1. IL-15 has effects similar to those of IL-7 in memory T cells and naïve CD8 ${ }^{+}$cells, but not naïve CD4 ${ }^{+}$cells. However, IL-4 maintains Mcl-1 and $\mathrm{Bcl}-2$ but also upregulates Bim and Bcl-2-associated X protein (Bax), thus altering the cell's dependence on Mcl-1.

Cell Death and Disease (2011) 2, e214; doi:10.1038/cddis.2011.95; published online 6 October 2011

Subject Category: Immunity

The balanced production, maintenance, replication, and clearance of $\mathrm{T}$ cells is termed as homeostasis. Antigeninexperienced ('naïve') $T$ cells require homeostatic signals, typically low-level signals from self-peptide-major histocompatibility complex (MHC), and the cytokine IL-7. ${ }^{1}$ Upon activation, $\mathrm{T}$ cells expand into effector populations before 'contracting' into antigen-experienced ('memory') populations that are retained over time. Unlike naïve cells, memory cells do not require self-peptide-MHC and can utilize IL-15 for survival. ${ }^{1}$

IL-7 and other cytokines, namely IL-2, IL-15, IL-4, IL-9, and $\mathrm{IL}-21$, constitute a family that shares the $\gamma \mathrm{c}$-receptor subunit. The cytokine receptors are composed of the $\gamma c$ subunit with one or two other subunit(s), some shared and some unique. Each cytokine has a distinct biological role, although several of them, particularly IL-7 and IL-15, promote T-cell survival. ${ }^{2}$ Studies from mice, primary cells, and cell lines have implicated the B-cell lymphoma-2 (Bcl-2) family, specifically

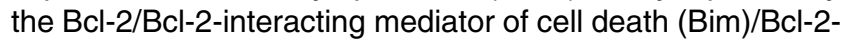
associated $X$ protein (Bax) axis, downstream of cytokine signaling, ${ }^{3}$ but the role of myeloid cell leukemia sequence-1 (Mcl-1) in cytokine-induced survival is less well described.
The $\mathrm{Bcl}-2$ family proteins are defined as sharing one or more Bcl-2 homology $(\mathrm{BH})$ domains. Pro-apoptotic Bcl-2 homologous antagonist/killer (Bak) and Bax self-oligomerize to form pores in mitochondrial membranes, and are required for the intrinsic pathway of apoptosis. ${ }^{4,5}$ Pro-apoptotic $\mathrm{BH} 3-$ only proteins, such as Bim, Bid, Bad, Noxa, and Puma, are upstream initiators. Anti-apoptotic proteins, including Bcl-2, $\mathrm{Mcl}-1$, and $\mathrm{Bcl}-\mathrm{x}_{\mathrm{L}}$, have been proposed to function both by inhibiting the $\mathrm{BH} 3$-only proteins and by inhibiting Bak/Bax. ${ }^{6-11}$ Which of these roles is dominant has been debated and has not been thoroughly explored in vivo.

Knockout mouse models have demonstrated the importance of $\mathrm{Bcl}-2$ family proteins in T-lymphocyte survival. Bak/Bax double-knockout mice, but not single-knockouts, exhibit increased numbers of $\mathrm{T}$ cells, T-cell resistance to apoptosis, and defective thymic selection. ${ }^{12,13}$ Both Bcl-2 and $\mathrm{Mcl}-1$ are required for survival in developing thymocytes and mature $\mathrm{T}$ cells. ${ }^{14-18}$ Inhibition of Bak by $\mathrm{Mcl}-1$ is critical in thymocytes: Bak deficiency, but not Bax deficiency or Bcl-2 overexpression, rescued the phenotype of Mcl-1-deficient thymocytes. ${ }^{19}$ Although Bim is important in thymocyte negative selection, and the $\mathrm{Bim}^{-1-}$ background rescued

\footnotetext{
${ }^{1}$ Department of Immunology, Duke University Medical Center, Durham, NC, USA

*Corresponding author: Y-W He, Department of Immunology, Duke University Medical Center, Jones Building 335, Box 3010, Research Drive, Durham, NC 27710 , USA. Tel: + 919613 7870; Fax: + 919684 8982; E-mail: he000004@duke.edu

Keywords: Mcl-1; Bcl-2; Bim; T lymphocytes; cytokines; common $\gamma$ chain

Abbreviations: 4OHT, 4-hydroxytamoxifen; Bak, Bcl-2 homologous antagonist/killer; Bax, Bcl-2-associated X protein; Bcl-2, B-cell lymphoma 2; Bim, Bcl-2-interacting mediator of cell death; BSA, bovine serum albumin; ER, estrogen receptor; EtOH, ethanol; FBS, fetal bovine serum; HRP, horseradish peroxidase; IL, interleukin; Mcl-1, myeloid cell leukemia sequence 1; MFI, mean fluorescence intensity; MHC, major histocompatibility complex; PBS, phosphate-buffered saline; PE, phycoerythrin; $\mathrm{PI}$, propidium iodide; RBC, red blood cell; SDS-PAGE, sodium dodecyl sulfate-polyacrylamide gel electrophoresis; TCR, T-cell receptor

Received 21.6.11; revised 19.7.11; accepted 08.8.11; Edited by P Salomoni
} 
Bcl-2-deficient thymocyte survival, ${ }^{20-22}$ Bim deficiency did not improve survival in Mcl-1-deficient thymocytes. ${ }^{19}$

Peripheral T cells die upon drug-induced deletion of Mcl-1 in vivo and under different in vitro conditions. ${ }^{17,18}$ However, the mechanism(s) by which $\mathrm{Mcl}-1$ promotes peripheral T-cell survival and the effect, if any, of trophic cytokines on these mechanisms are not yet understood. In this study, we utilize genetic models to investigate the mechanisms by which $\mathrm{Mcl}-1$ promotes peripheral T-lymphocyte survival. We examine the survival of $\mathrm{Mcl}-1-$ deficient cells on $\mathrm{Bak}^{-1-}, \mathrm{Bax}^{-1-}$, $\mathrm{Bim}^{-1-}$, and $\mathrm{Bcl}-2-$ overexpressing backgrounds in the presence and absence of IL-7 and other $\gamma \mathrm{C}$-sharing cytokines. The data highlight the complex pathways that regulate primary T-cell survival, particularly the role of $\mathrm{Mcl}-1$, and the functions of $\gamma \mathrm{c}$ cytokines.

\section{Results}

Mcl-1 is required for $\mathrm{CD}^{+}{ }^{+}$and $\mathrm{CD}^{+}{ }^{+}$, naïve and memoryphenotype T-cell survival. The estrogen receptor-Cre fusion protein (ERCre) allows deletion of floxed genes upon addition of the drug tamoxifen, or its active metabolite 4-hydroxytamoxifen $(4 \mathrm{OHT}){ }^{23}$ We previously showed that 4OHT-treated T cells from Mcl-1-floxed, ERCre-expressing (Mcl-1 $1^{\mathrm{f} / \mathrm{f}}$ ERCre) mice died under different ex vivo conditions. ${ }^{18}$ As in vivo studies using this model were precluded by rapid morbidity in tamoxifen-treated $\mathrm{Mcl}-1$-floxed estrogen receptorCre fusion protein (Mcl-1/f ERCre) mice, we used the in vitro system to dissect the individual and combinatorial effects of $\mathrm{Bcl}-2$ family proteins and trophic cytokines on $\mathrm{Mcl}-1$ activity.

To assess whether $\mathrm{Mcl}-1$ deletion differentially affects T-cell subsets, we examined survival in Mcl-1-deleted T-cell subsets. To assess the effect of IL-7, we added IL-7 to $1 \mathrm{ng} / \mathrm{ml}$, a concentration that is commonly used in T-cell biology, and that is thought to be physiological. Similar to previous results, ${ }^{18} \mathrm{CD}^{+}$and $\mathrm{CD}^{+}{ }^{+} \mathrm{Mcl}-1^{\mathrm{f} / \mathrm{f}}$ ERCre T-cells had reduced survival upon $\mathrm{Mcl}-1$ deletion in a 3-day culture of splenocytes in medium alone, with IL-7 (Figure 1a), and with activating anti-CD3/CD28 antibodies (data not shown).

As baseline survival varied between conditions, we calculated the ratio of survival with $4 \mathrm{OHT}$ to survival with vehicle control (ethanol, EtOH) to have a better comparison of the effect of $\mathrm{Mcl}-1$ deletion. The magnitude of the reduction in survival upon deletion is a measure of $\mathrm{Mcl}-1$ dependency. The $4 \mathrm{OHT} / \mathrm{EtOH}$ survival ratio was approximately 1 in ERCrenegative samples (Figure $1 \mathrm{~b}$ ). The reduction in survival was more severe in cells cultured in medium alone than in those cultured with IL-7, indicating greater dependence on $\mathrm{Mcl}-1$ without IL-7 (Figure 1b). IL-7 enhanced survival in Mcl-1sufficient (ERCre-negative and EtOH-treated) cells by 5-10fold, but enhanced survival in Mcl-1-deficient cells by 20-30fold (Figure 1c).

We observed differences in absolute survival between CD44 ${ }^{\mathrm{hi}}$ memory-phenotype and CD44 ${ }^{\mathrm{lo}}$ naïve cells (Figure 1e, gating shown in Figure 1d). However, the relative reduction in survival upon $\mathrm{Mcl}-1$ deletion was similar between CD44 ${ }^{\mathrm{hi}}$ and $\mathrm{CD} 44^{\mathrm{lo}}$ cells, and all T-cell subsets required $\mathrm{Mcl}-1$ (Figure 1e). To confirm that cells in our culture conditions deleted $\mathrm{Mcl}-1$, we assessed $\mathrm{Mcl}-1$ protein expression by flow cytometry to allow side-by-side comparison of survival and $\mathrm{Mcl}-1$ levels. Although baseline $\mathrm{Mcl}-1$ fluorescence was quite low, we detected a loss of $\mathrm{Mcl}-1$ signal in $4 \mathrm{OHT}$-treated cells using the same time-point and culture conditions used to assess survival (Figure 1f).

$\mathrm{Bak}^{-\prime-}$ rescues Mcl-1-deficient T-cell survival in IL-7, but not during cytokine withdrawal. In a previous study, Bak deficiency rescued Mcl-1-deficient thymocyte survival, and we observed rescued $\mathrm{T}$-cell numbers in $\mathrm{Bak}^{-1-} \mathrm{Mcl}-1^{\mathrm{f} / \mathrm{f}}$ CD4Cre spleens. ${ }^{19}$ To determine the importance of Bak inhibition in peripheral T cells, we compared $\mathrm{Mcl}-1^{\mathrm{f} / \mathrm{f}} \mathrm{ERCre}$ $\mathrm{T}$-cell survival with that of $\mathrm{Bak}^{-/-} \mathrm{Mcl}-1^{\mathrm{f} / \mathrm{f}} \mathrm{ERCre}$ cells following deletion. In medium alone, $\mathrm{Bak}^{-1-} \mathrm{Mcl}-1^{\mathrm{f} / \mathrm{f}} \mathrm{ERCre}$ $\mathrm{T}$ cells survived no better than $\mathrm{Mcl}-1^{\mathrm{f} / \mathrm{f}} \mathrm{ERCre}$ cells as measured by the percent survival or $4 \mathrm{OHT} / \mathrm{EtOH}$ survival ratio (Figures $2 \mathrm{a}$ and $\mathrm{c}$ ). In contrast, the survival of $\mathrm{Bax}^{-1-} \mathrm{Mcl}-1^{\mathrm{f} / \mathrm{f}} \mathrm{ERCre} \mathrm{T}$ cells was slightly higher than that of $\mathrm{Bax}^{+/+}$controls, although the difference in the ratio was not significant for $\mathrm{CD}^{+}$cells (Figures $2 \mathrm{~b}$ and $\mathrm{c}$ ). Bax has been previously implicated in cytokine withdrawal-induced apoptosis in thymocytes. ${ }^{24}$

To better mimic homeostatic conditions, we added IL-7 to the medium. 4OHT-treated $\mathrm{Bak}^{-1-} \mathrm{Mcl}-1^{\mathrm{f} / \mathrm{f}} \mathrm{ERCre} \mathrm{T}$ cells had comparable survival to EtOH-treated, wild-type, and $\mathrm{Bak}^{-/-}$ ERCre $^{\text {neg }}$ controls (Figures $2 d$ and f). Bax deficiency did not rescue $\mathrm{Mcl}-1$-deleted $\mathrm{T}$ cells in IL-7 (Figures $2 \mathrm{e}$ and $\mathrm{f}$ ). To address the possibility that Bak deficiency altered the kinetics of survival but not the ultimate fate of Mcl-1-deleted cells, we assessed survival over a 5-day period. The Bak ${ }^{-1-}$ background rescued $\mathrm{Mcl}-1$-deficient cell survival for 5 days upon addition of a single dose of $\mathrm{IL}-7$ at the beginning of culture (Figure $2 \mathrm{~g}$ ).

To confirm that the rescue of Mcl-1-deleted cells by knockout genotypes was not due to the expansion of Mcl-1expressing cells ('escapers'), we determined the relative expression of $\mathrm{Mcl}-1$ in knockout versus wild-type cells at baseline and upon $\mathrm{Mcl}-1$ deletion. Baseline Mcl-1 levels in $\mathrm{Bak}^{-1-}$ and $\mathrm{Bim}^{-1-}$ (discussed below) cells were equivalent to those in wild-type counterparts (Supplementary Figure S1). $\mathrm{Bax}^{-1-}$ cells contained slightly higher levels of $\mathrm{Mcl}-1$ than $\mathrm{Bax}^{+/+}$cells in the medium alone. Importantly, we did not detect an increase in relative $\mathrm{Mcl}-1$ expression in doubleknockout samples upon $\mathrm{Mcl}-1$ deletion (Supplementary Figure S1), indicating that rescue genotypes do not select for escapers.

Bcl-2 rescues cytokine dependency, but not the requirement for $\mathbf{M c l}-1$, in $\mathbf{T}$ cells. $\mathrm{Bcl}-2$ overexpression rescued $\mathrm{T}$-cell development and survival in $\mathrm{IL}^{-7 \mathrm{R}^{-/-}}$mice but failed to rescue Mcl-1-deficient thymocyte development. ${ }^{19,25,26}$ To determine whether Bcl-2 modulates Mcl-1-deficient peripheral T-cell survival, we used mice expressing a Bcl-2 transgene using the MHC class-I promoter $\left(\mathrm{Bcl}-2^{\text {tg }}\right.$ mice $) .{ }^{27} \mathrm{Bcl}-2$ overexpression rescued undeleted T-cell survival in medium alone to the levels observed with IL-7 (Figure 3a). We observed a slight improvement over wild-type cells in $\mathrm{Bax}^{-1-}$ but not Bak ${ }^{-/-}$ cell survival, but the modest improvement indicates that cytokine withdrawal-induced apoptosis occurs largely 
a

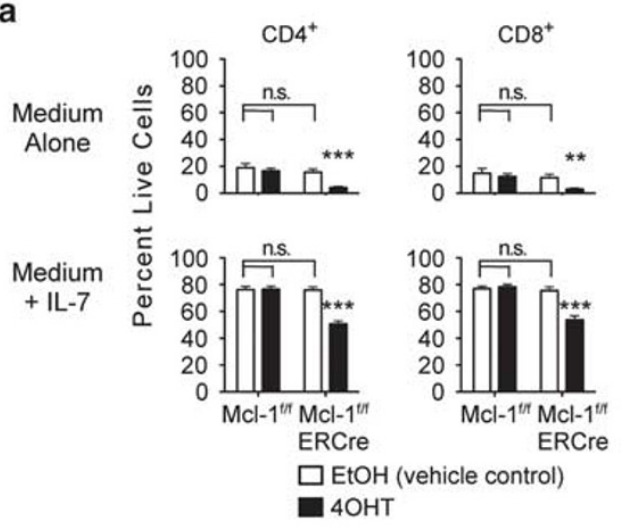

b $\mathrm{CD}^{+} \quad \mathrm{CD}^{+}$ 4OHT:EtOH Survival Ratio

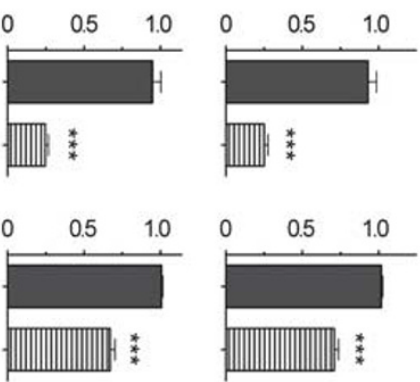

$\mathrm{Mcl}-1^{\mathrm{f} / \mathrm{f}}$

III $\mathrm{Mcl}-1^{\mathrm{f} / \mathrm{E}} \mathrm{ERCre}$

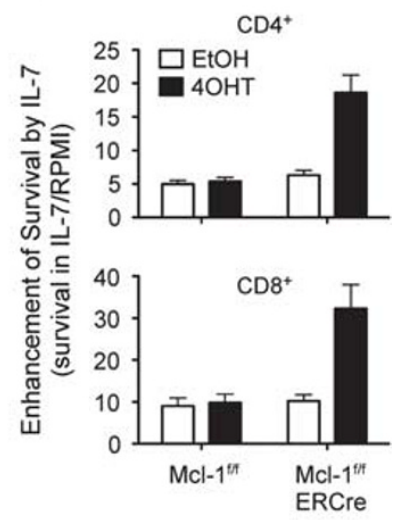

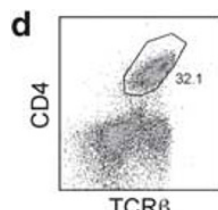
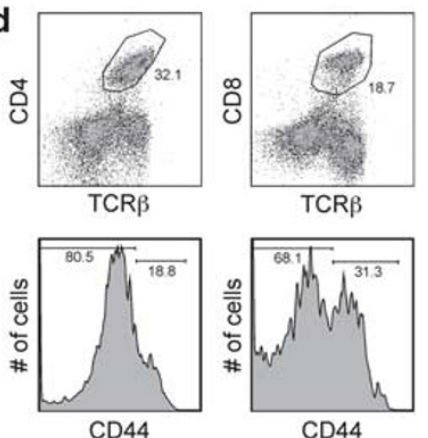

e

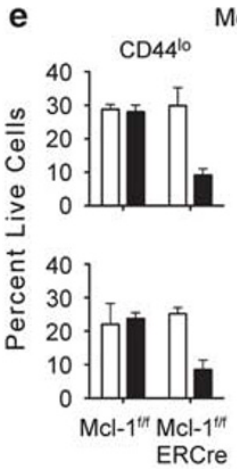

Medium Alone
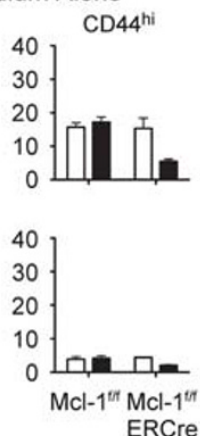
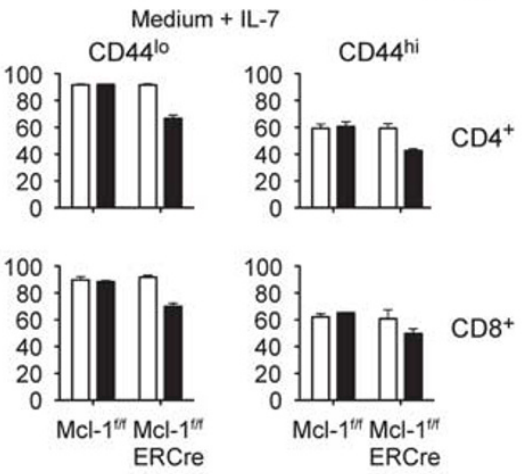

f

Medium Alone

Medium + IL-7
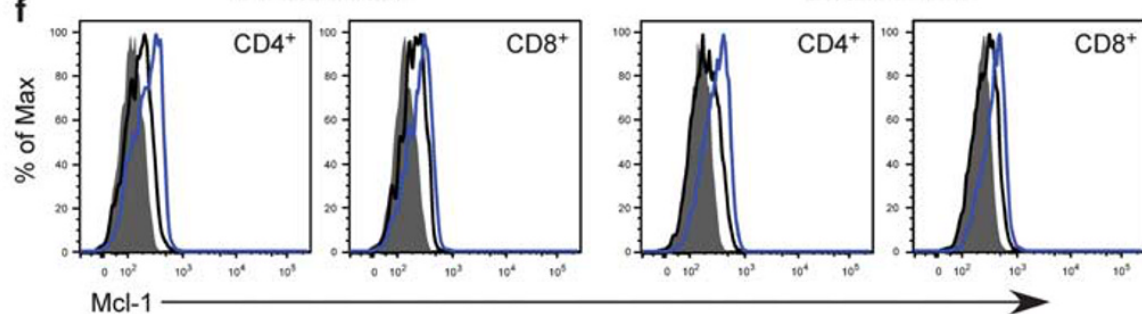

- EtOH

- 4OHT

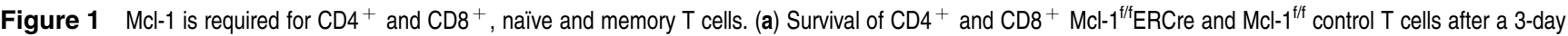
culture of total splenocytes in medium alone and in medium with $1 \mathrm{ng} / \mathrm{ml} \mathrm{IL-7.} \mathrm{The} \mathrm{percentage} \mathrm{of} \mathrm{live} \mathrm{cells} \mathrm{was} \mathrm{assessed} \mathrm{by} \mathrm{PI} \mathrm{exclusion.} \mathrm{White} \mathrm{bars} \mathrm{represent} \mathrm{cells} \mathrm{cultured}$ in the ethanol vehicle control $(\mathrm{EtOH})$, and black bars represent cells cultured in 4-hydroxytamoxifen (4OHT). The data represent the mean survival + S.E.M. of 12-15 experiments, each performed in triplicate. Here, n.s. signifies that the $P$ value is not significant $(P \geq 0.05)$ between the samples indicated. ${ }^{* \star} P<0.01$, ${ }^{* \star \star} P<0.001$ versus $4 \mathrm{OHT}$-treated Mcl- ${ }^{\text {t/f }}$ control. (b) Ratio of survival in $4 \mathrm{OHT}$ to survival in EtOH of splenocytes cultured for 3 days in medium alone and in medium $+\mathrm{IL}-7$. The ratios calculated from triplicate wells were determined for each experiment, and the bars represent the mean of the ratios + the S.E.M. of $12-15$ experiments. ${ }^{* \star *} P<0.001$ versus Mcl- $1^{t / f}$ control. (c) The enhancement of survival by IL-7 was calculated by dividing the percent survival (as assessed by PI exclusion) in medium with IL-7 (1 $\mathrm{ng} / \mathrm{ml}$ ) by the survival in medium alone for each cell type in both the EtOH control and 4OHT as indicated. The bars are the mean + S.E.M. of 11-14 independent experiments. (d) Gating of CD44 ${ }^{\text {hi }}$ and $\mathrm{CD} 44^{\mathrm{lo}}$ cells from total splenocyte cultures. Representative flow cytometry plots and histograms are shown. Cells were pre-gated on both live and dead cell populations by forward and side scatter. (e) Percent surviving cells by PI exclusion in total splenocyte cultures gated on CD $44^{\text {hi }}$ and CD $44^{10}$ populations. Bars are the mean + S.D. of triplicate wells. (f) Mcl-1 protein expression was assessed by intracellular staining for Mcl- 1 in cells cultured for 3 days with or without $4 \mathrm{OHT}$. The shaded histogram indicates the isotype control. Data are representative of three experiments, each with duplicate wells

through Bak or Bax (Figure 3a). Bim ${ }^{-1-}$ cells were resistant to cytokine withdrawal-induced cell death (Figure $3 a$ and Bouillet $\mathrm{P}$ et $a .^{28}$ ).

Upon $\mathrm{Mcl}-1$ deletion, $\mathrm{Bcl}-2^{\mathrm{tg}} \mathrm{Mcl}-1^{\mathrm{f} / \mathrm{f}} \mathrm{ERCre}$ cells had improved survival over $\mathrm{Mcl}-1^{\mathrm{f} / \mathrm{f}} \mathrm{ERCre}$ cells in medium alone as measured by the percent survival and the $4 \mathrm{OHT} / \mathrm{EtOH}$ survival ratio (Figures $3 \mathrm{~b}$ and $\mathrm{d}$ ). $\mathrm{Bcl}-2$ overexpression did not completely rescue survival in $4 \mathrm{OHT}$-treated $\mathrm{Bcl}-2^{\mathrm{tg}} \mathrm{Mcl}-1^{\mathrm{f} / \mathrm{f}}$ ERCre cells to EtOH control (percent survival, Figure $3 b$ ) or wild-type (ratio, Figure 3d) levels. With IL-7, which induces endogenous $\mathrm{Bcl}-2$, the survival of $\mathrm{Bcl}-2^{\mathrm{tg}} \mathrm{Mcl}-1^{\mathrm{f} / \mathrm{f}} \mathrm{ERCre}$ cells was not different from that of $\mathrm{Mcl}-1^{\mathrm{f} / \mathrm{f}} \mathrm{ERCre}$ cells (Figures $3 \mathrm{c}$ and e). Therefore, IL-7 and $\mathrm{Bcl}-2$ have similar effects on $\mathrm{Mcl}-1$ activity. In spite of the partial rescue during cytokine withdrawal, Bcl-2 overexpression did not stabilize Mcl-1deficient T-cell survival over time (Figure 3f), nor did $\mathrm{Bcl}-2$ overexpression alter the kinetics of $\mathrm{Mcl}-1$ deletion-induced death in IL-7 (Figure 3g). 
c $4 \mathrm{OHT}$ :EtOH Survival Ratio in RPMI

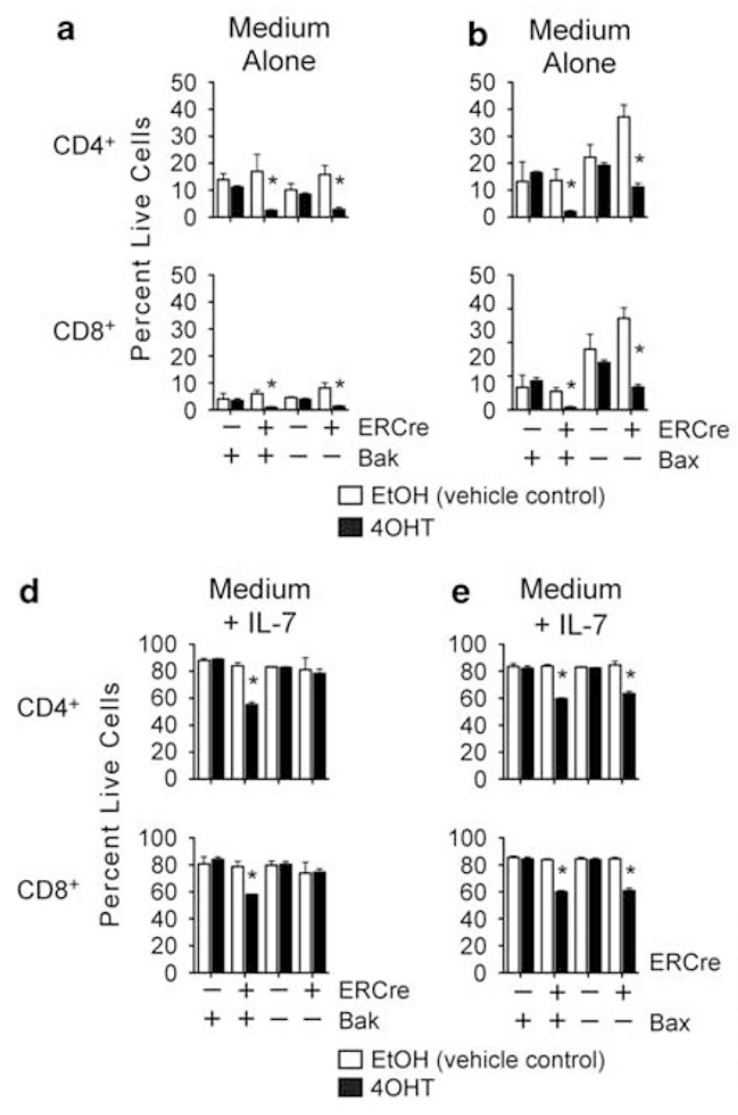

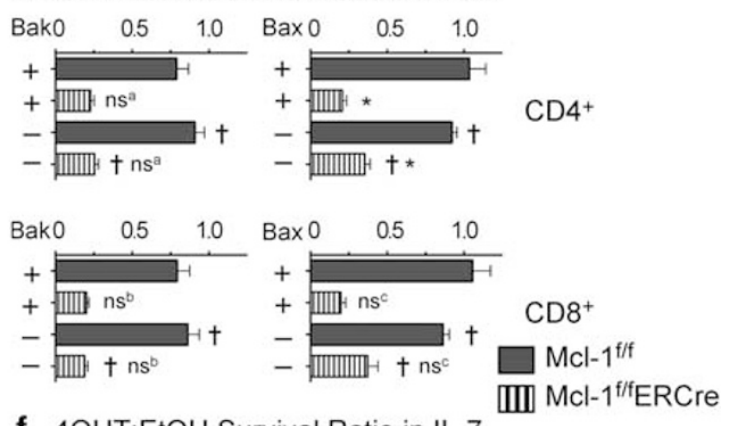

f $4 \mathrm{OHT}$ :EtOH Survival Ratio in IL-7
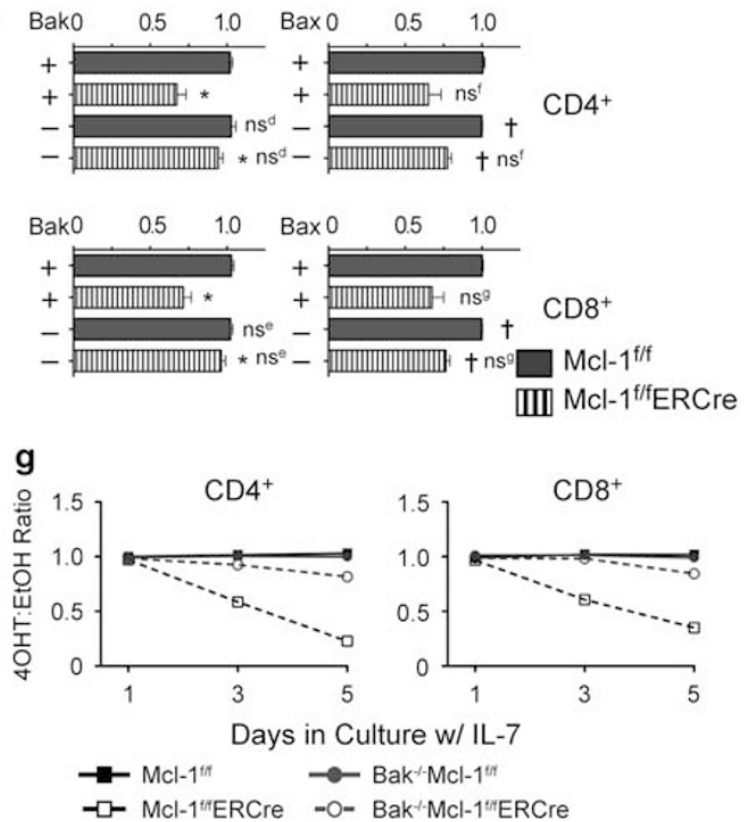

Figure $2 \mathrm{Bak}^{-1-}$ but not Bax ${ }^{-1-}$ rescues the survival of Mcl-1-deficient cells in IL-7 but not during cytokine withdrawal. (a and $\left.\mathbf{b}\right)$ Percent surviving Bak $^{-1-}(\mathbf{a})$ and Bax ${ }^{-1-}$ (b) $\mathrm{Mcl}^{1 / / /}$ and $\mathrm{Mcl}-1^{\mathrm{t} / \mathrm{E}} \mathrm{ERCre}$ cells by PI exclusion after 3 days in culture in medium alone. Bars are the mean + S.D. of triplicate wells. Data are representative of three independent experiments each for $\mathrm{Bak}^{-1-}$ and $\mathrm{Bax}^{-1-}$. ${ }^{*} P<0.05$ versus EtOH control within each genotype. (c) Survival ratios of Bak ${ }^{-1-}$ and Bax ${ }^{-1-}$ cells upon 3 -day culture in medium alone (RPMI). Bars are the mean + S.E.M. of three experiments. ${ }^{\star} P<0.05$ between the ERCre ${ }^{+}$samples. ${ }^{\dagger} P<0.05$ between ERCre ${ }^{+}$and ERCre ${ }^{\text {neg }}$ samples within the $\mathrm{Bak}^{-1-}\left(\mathrm{Bax}^{-1-}\right.$ in f) genotype. Here, ns indicates that $P \geq 0.05$ between the indicated samples (designated by lower case letters). (d and e) Percent surviving $\mathrm{Bak}^{-1-}$ (d) and $\mathrm{Bax}^{-1-}$ (e) cells by PI exclusion after 3 days in culture in IL-7. Bars are the mean + S.D. of triplicate wells. Data are representative of three independent experiments. ${ }^{*} P<0.05$ versus EtOH control for each genotype. (f) Survival ratios of $\mathrm{Bak}^{-1-}$ and Bax ${ }^{-1-}$ cells upon 3-day culture in IL-7. Bars are the mean + S.E.M. of three experiments. Statistical significance is depicted as in c. (g) Time course of survival of control and Bak ${ }^{-l-}$, Mcl- ${ }^{f / f}$, and Mcl-1/f/f ERCre T cells in IL-7. The mean $4 \mathrm{OHT} / \mathrm{EtOH}$ survival ratios from two experiments are plotted versus time

\begin{abstract}
$\mathrm{Bim}^{-1-}$ partially rescues $\mathrm{T}$-cell cytokine dependency, but not the requirement for $\mathrm{Mcl}-1$. Bim has been shown to be induced by cytokine withdrawal, and to modulate T-cell cytokine dependency. ${ }^{28,29}$ We observed that $\mathrm{Bim}^{-1-}$ cells survived better than wild-type cells during cytokine withdrawal (Figure 3a). In medium alone, $\mathrm{Bim}^{-/-} \mathrm{Mcl}-1^{\mathrm{t} / \mathrm{f}}$ ERCre T cells, particularly $\mathrm{CD}^{+}$, had improved survival compared with $\mathrm{Mcl}-1^{\mathrm{t} / \mathrm{f}} \mathrm{ERCre}$ cells (Figures $4 \mathrm{a}$ and $\mathrm{b}$ ). Similar to Bcl-2 overexpression, Bim deficiency did not improve survival in IL-7 (Figures $4 \mathrm{c}$ and d). Therefore, inhibiting Bim is not the major role of Mcl-1 in T cells in IL-7, but Bim likely contributes to the accelerated death of $\mathrm{Mcl}$-1-deficient T cells during cytokine withdrawal.
\end{abstract}

Modulation of the roles of Mcl-1 by $\gamma \mathrm{c}$ cytokines. As IL-7 altered the role of $\mathrm{Mcl}-1$ in T cells, we examined how other cytokines of the $\gamma c$ family affected T-cell dependence on Mcl-1. Naïve and memory $T$ cells respond differently to cytokines, so we examined the survival of CD44 $4^{\mathrm{lo}}$ and CD44 ${ }^{\text {hi }} \mathrm{T}$ cells in the presence of different cytokines. Although IL-2 promotes activated T-cell survival, resting cells do not express the high-affinity IL-2 receptor, and we did not observe a survival response to IL-2 in our system (data not shown). We selected concentrations of IL-4 and IL-15 that were previously shown to promote T-cell survival and $\mathrm{Mcl}-1$ expression $(1-10 \mathrm{ng} / \mathrm{ml}),{ }^{17,30}$ and a dose-response experiment confirmed that the lower concentrations $(0.1 \mathrm{ng} / \mathrm{ml})$ did not effectively promote T-cell survival (Supplementary Figure S2). Consistent with published results, ${ }^{30,31} \mathrm{IL}-4$ at 1 and $10 \mathrm{ng} / \mathrm{ml}$ improved the survival of CD44 ${ }^{\text {lo }}$ (Figure $5 \mathrm{a}$ ) and CD44 $4^{\text {hi }}$ (Figure $5 \mathrm{~b}$ ) T cells over that of cells cultured in medium alone. The survival of 


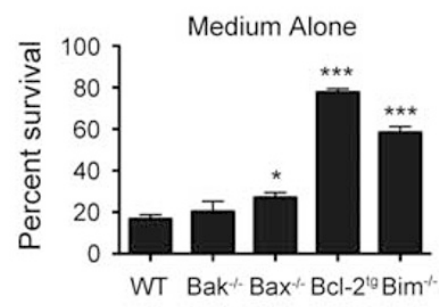

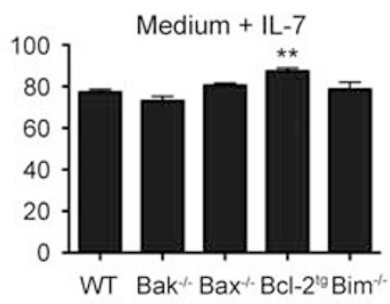

Medium + IL-7
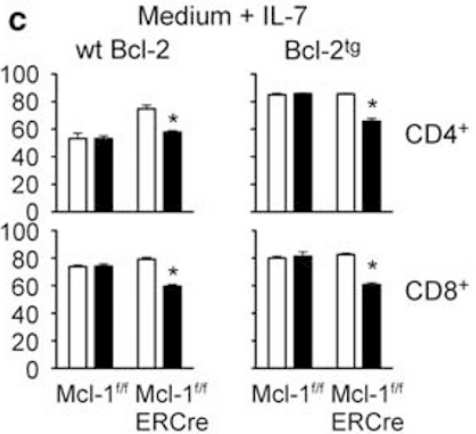

d

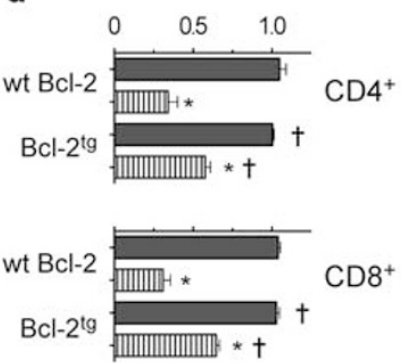

e

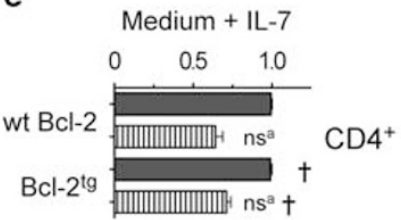

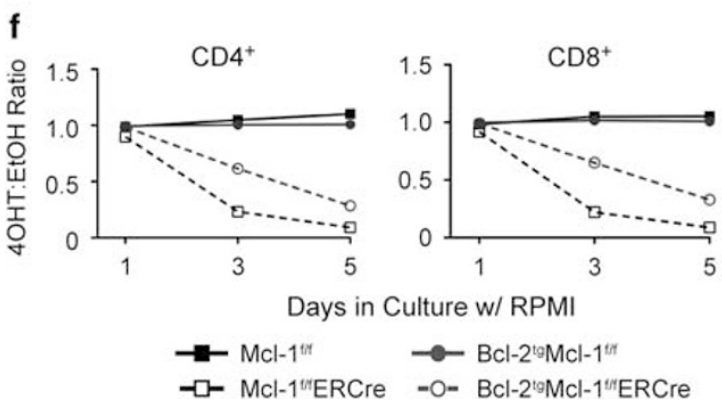

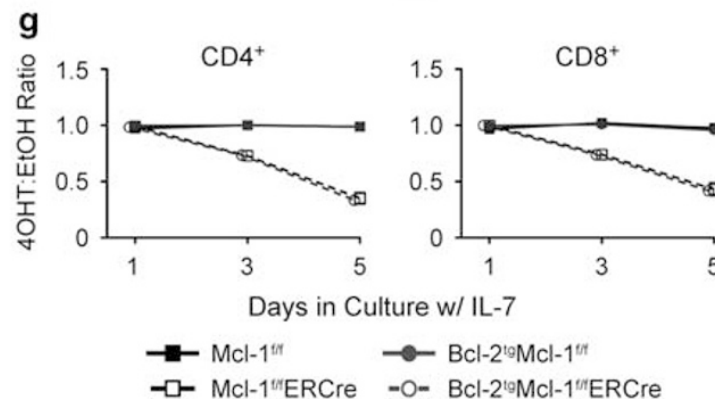

Figure 3 Overexpression of Bcl-2 rescues cells from cytokine dependence but not dependence on Mcl-1. (a) Percent survival by PI exclusion of wild type (WT), Bak ${ }^{-1-}$, $\mathrm{Bax}^{-l-}, \mathrm{Bcl}-2^{\mathrm{tg}}$, and Bim ${ }^{-l-} \mathrm{T}$ cells in culture of total splenocytes with or without IL-7 for 3 days. ${ }^{*} P<0.05,{ }^{* \star} P<0.01,{ }^{\star \star *} P<0.001$ versus WT control. Items not marked with an asterisk are not significant $(P \geq 0.05)$. (b and $\mathbf{c})$ Percent surviving cells by PI exclusion after 3-day culture of total splenocytes without (b) and with (c) IL-7. Cells overexpressing Bcl-2 $\left(\mathrm{Bcl}-2^{\text {tg }}\right)$ and cells expressing only endogenous Bcl-2 (wt Bcl-2) are shown. The $\mathrm{y}$-axis scale is the same for the wt Bcl-2 and adjacent Bcl-2 ${ }^{\text {tg }}$ graphs. Bars are mean + S.D. of triplicate wells from a single experiment. Data are representative of four independent experiments. ${ }^{*} P<0.05$ versus EtOH control within each genotype. (d and e) Survival ratios of wt Bcl-2 and Bcl-2tg cells upon 3-day culture in medium alone (d) or in IL-7 (e). Bars are the mean + S.E.M. of 4-6 independent experiments. ${ }^{\star} P<0.05$ between the ERCre ${ }^{+}$samples. ${ }^{\dagger} P<0.05$ between ERCre ${ }^{+}$and $\mathrm{ERCre}{ }^{\text {neg }}$ samples within the $\mathrm{Bcl}-2^{\mathrm{tg}}$ genotype. Here, ns indicates that $P \geq 0.05$ between the indicated samples (designated by lower-case letters). ( $f$ and $\mathbf{g}$ ) Time course of survival of wt Bcl-2 and Bcl-2 $2^{\text {tg }}$, Mcl- $1^{1 / f}$, and Mcl- $1^{t / f}$ ERCre T cells in RPMl alone (f) or with IL-7 (g). The mean of the $4 \mathrm{OHT} / \mathrm{EtOH}$ survival ratios from 1-3 experiments is plotted versus time

CD $44^{\text {hi }}$ cells, particularly CD4 ${ }^{+}$CD $44^{\text {hi }}$ cells, was lower than CD44 ${ }^{\mathrm{lo}}$-cell survival. Upon $\mathrm{Mcl}-1$ deletion, T-cell survival in IL-4 was significantly diminished (Figures $5 a$ and b).

IL-15 promoted survival in CD44 ${ }^{\text {hi }}$ cells (Figure $5 \mathrm{~b}$ ), and CD44 ${ }^{\text {hi }}$ cells in IL-15 exhibited reduced survival upon $\mathrm{Mcl}-1$ deletion (Figure $5 \mathrm{~b}$ ). IL-15 at $10 \mathrm{ng} / \mathrm{ml}$ also promoted the survival of $\mathrm{CD}_{4} 4^{\mathrm{lo}} \mathrm{CD}^{+}{ }^{+} \mathrm{T}$ cells to a similar extent as IL-7 (Figure 5a). CD44 ${ }^{\mathrm{lo}} \mathrm{CD} 4{ }^{+} \mathrm{T}$ cells were not responsive to IL-15: the percent survival with $1 \mathrm{ng} / \mathrm{ml} \mathrm{IL-15}$ was similar to that in RPMI (slightly higher with $10 \mathrm{ng} / \mathrm{ml}$, Figure $5 \mathrm{a}$ ). These results are consistent with a well-documented difference in responsiveness to IL-15 between subsets, and could be due to receptor expression levels. ${ }^{32-34}$

The diminished survival upon $\mathrm{Mcl}-1$ deletion (measured by the $4 \mathrm{OHT} / \mathrm{EtOH}$ survival ratio) was more severe in IL-4 than in
IL-7, indicating that cells cultured in IL-4 were more sensitive to $\mathrm{Mcl}-1$ deletion (Figure $5 \mathrm{c}$ ). The survival ratio in IL-4 was not significantly different from that in RPMI alone. With IL-15, sensitivity to $\mathrm{Mcl}-1$ deletion correlated to the overall response to IL-15: non-responsive $\mathrm{CD} 44^{\mathrm{l}} \mathrm{CD} 4^{+}$cells were more sensitive than IL-15-responsive $\mathrm{CD} 44^{\mathrm{lo}} \mathrm{CD} 8^{+}$and $\mathrm{CD} 44^{\text {hi }}$ cells (Figure $5 c$ and data not shown).

Bak deficiency completely rescued IL-15-mediated survival in $\mathrm{Mcl}-1$-deleted responsive cells but not in non-responsive $\left(\mathrm{CD} 44^{\mathrm{lo}} \mathrm{CD} 4^{+}\right.$) cells (Figure $5 \mathrm{~d}$ ). In contrast, Bak deficiency did not completely rescue survival in $\mathrm{CD}^{+}{ }^{+}$or $\mathrm{CD}^{+}{ }^{+} \mathrm{T}$ cells in IL-4 (Figure $5 d$ ). This is consistent with the fact that $T$ cells in IL-4 were similar to cells cultured in RPMI in Mcl-1 dependence, and the $\mathrm{Bak}^{-1-}$ background did not rescue survival in RPMI. 

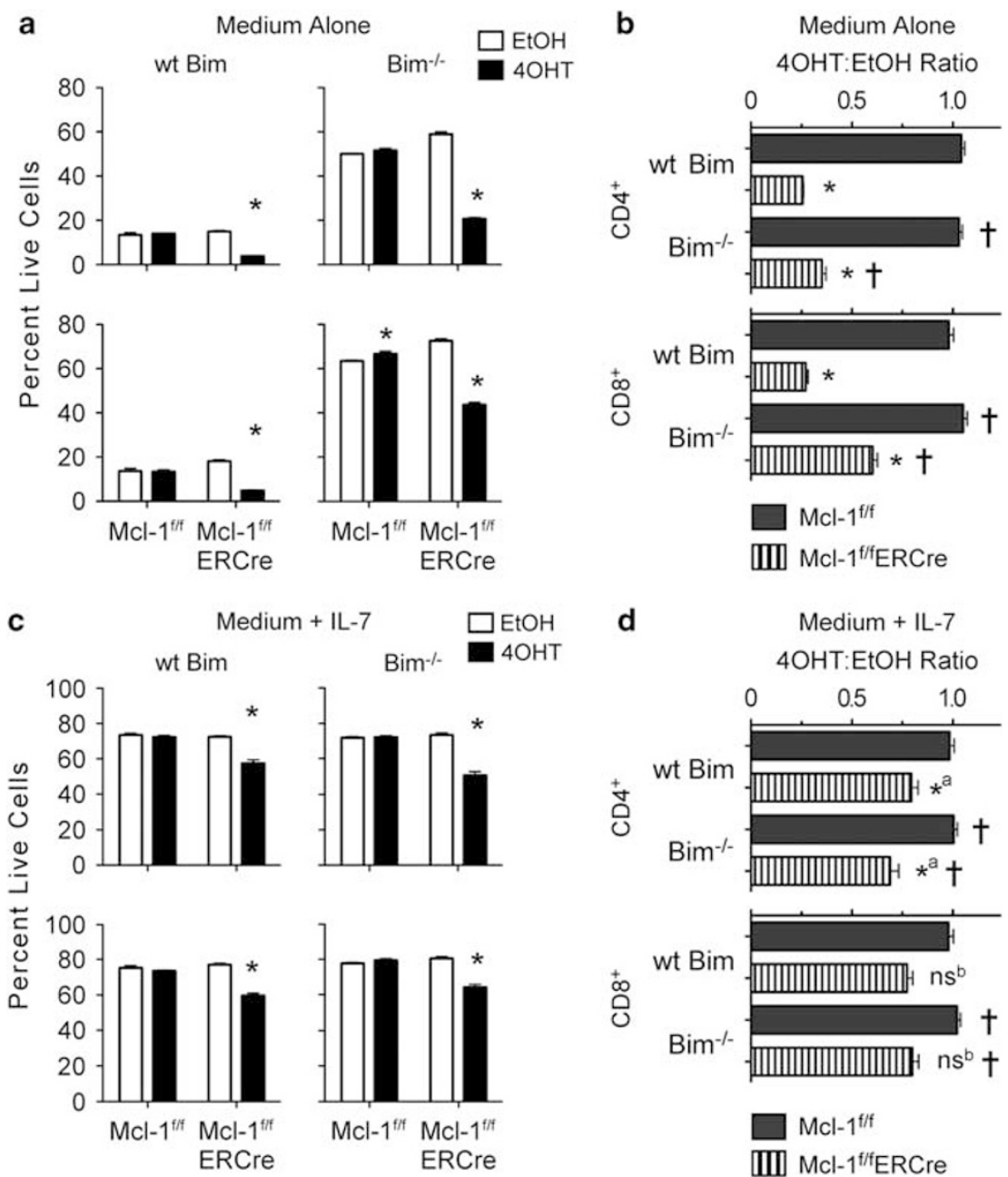

Figure $4 \mathrm{Bim}^{-1-}$ partially rescues survival of $\mathrm{Mcl}-1$-deficient cells in cytokine withdrawal. (a and $\left.\mathbf{b}\right)$ Percent surviving cells (a), and ratio of survival in $4 \mathrm{OHT} / \mathrm{EtOH}$ (b) of control and Bim ${ }^{-1-} \mathrm{Mcl}^{\mathrm{f} / / /}$ and Mcl-1//5ERCre cells cultured in medium alone. (c and d) Percent surviving cells (c) and ratio of survival in $4 \mathrm{OHT} / \mathrm{EtOH}$ (d) of control and Bim ${ }^{-1-}$ $\mathrm{Mcl}-1^{\mathrm{ft/f}}$ and Mcl-1//fERCre cells cultured in IL-7. Data in $\mathbf{a}$ and $\mathbf{c}$ are the mean + S.D. of triplicate wells from a single experiment and are representative of two independent experiments. ${ }^{*} P<0.05$ versus EtOH control within each genotype. The $y$-axis scale is the same for the wt Bim and adjacent Bim ${ }^{-1-}$ graphs. Data in $\mathbf{b}$ and $\mathbf{d}$ are the mean + S.D. .ratio of the ratios from one representative of two experiments. ${ }^{*} P<0.05$ between the ERCre ${ }^{+}$samples. ${ }^{* a}$ the Bim ${ }^{-1-}$ survival is significantly lower. ${ }^{\dagger} P<0.05$ between $\mathrm{ERCre}^{+}$and ERCre ${ }^{\text {neg }}$ samples within the $\mathrm{Bim}^{-1-}$ genotype. Here, ns indicates that $P \geq 0.05$ between the indicated samples (designated by lower-case letters)

We also compared the enhancement of survival (over that of $\mathrm{Mcl}-1^{\mathrm{t} / \mathrm{E}} \mathrm{ERCre}$ cells) between $\mathrm{Bax}^{-1-}$ and $\mathrm{Bcl}-2^{\mathrm{tg}}$ genotypes in IL-4 or IL-15. A value of 1 indicates that the $\mathrm{Bax}^{-/-}$or Bcl-2 ${ }^{\text {tg }}$ background did not enhance survival. Neither Bax deficiency nor $\mathrm{Bcl}-2$ overexpression affected baseline survival in IL-4 (Figure 5e). Upon Mcl-1 deletion, $\mathrm{Bcl}^{2} 2^{\text {tg }}$ but not $\mathrm{Bax}^{-1-}$ cells had enhanced survival, indicating that, unlike in IL-7, $\mathrm{Bcl}-2$ and $\mathrm{Mcl}-1$ share a role in promoting cell survival in IL-4 (Figure $5 \mathrm{e}$ ). Neither the $\mathrm{Bcl}-2^{\text {tg }}$ nor the $\mathrm{Bax}^{-1-}$ background greatly enhanced $\mathrm{CD}^{+}$cell survival in $\mathrm{IL}-15$, but $\mathrm{Bcl}-2$ overexpression rescued both $\mathrm{Mcl}-1$-sufficient and $\mathrm{Mcl}-1$ deficient CD4 ${ }^{+}$CD44 $4^{\mathrm{lo}}$ cells in IL-15 (Figure $5 \mathrm{e}$ ).

As cells in vivo likely encounter multiple cytokines simultaneously, we assessed the effect of multiple cytokines on Mcl-1 dependence. T cells cultured with a mix of IL-4, IL-7, and IL-15 had a survival rate equal to that in any of the cytokines alone (Figures $5 a$ and $b$ ). Strikingly, cells cultured in the cytokine mix were more dependent on Mcl-1 than cells in IL-7 or IL-15
(CD8 ${ }^{+}$cells), and the $4 \mathrm{OHT} / \mathrm{EtOH}$ survival ratio matched that of IL-4 (Figure 5c). Like Mcl-1-deficient cells in IL-4 alone, the survival of Mcl-1-deficient cells in the cytokine mix was enhanced by Bcl-2 overexpression, indicating that the effect of IL-4 on the role of Mcl-1 (favoring the shared versus unshared role with $\mathrm{Bcl}-2$ ) is dominant over the effect of IL-7.

Modulation of Bcl-2 family proteins by $\gamma \mathrm{c}$ cytokines. To determine why $\mathrm{T}$ cells cultured in IL-4, IL-7, and IL-15 had differing levels of dependence on Mcl-1, we examined protein expression for selected $\mathrm{Bcl}-2$ family members upon culture with different $\gamma \mathrm{c}$ cytokines. IL-4, IL-7, and IL-15 induced higher expression of $\mathrm{Mcl}-1$ and $\mathrm{Bcl}-2$ than IL-2 or RPMI on day 3 (Figures $6 a$ and b). Surprisingly, Bim was upregulated in the pro-survival cytokines, and this upregulation was most pronounced in IL-4 (Figures 6a and b). The upregulation of Bim by IL-4 was also observed on day 1 by intracellular staining (data not shown) and to a 
a

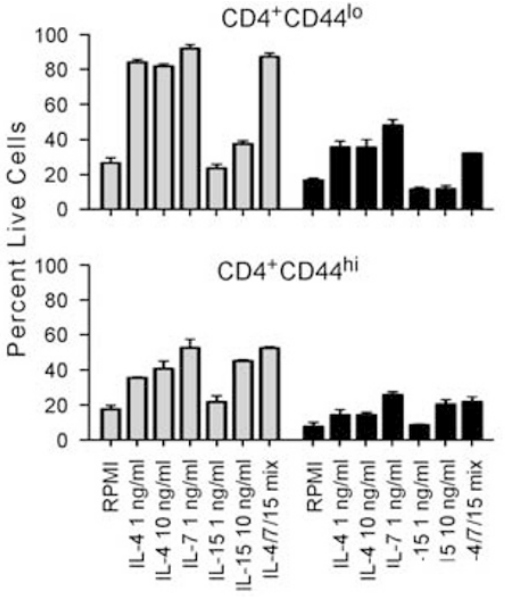

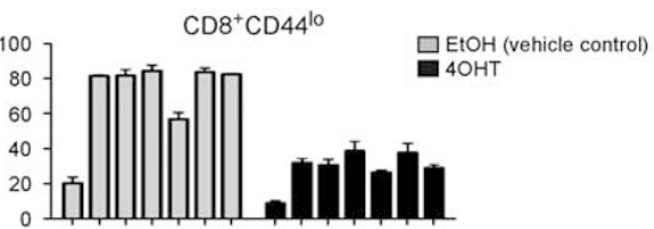

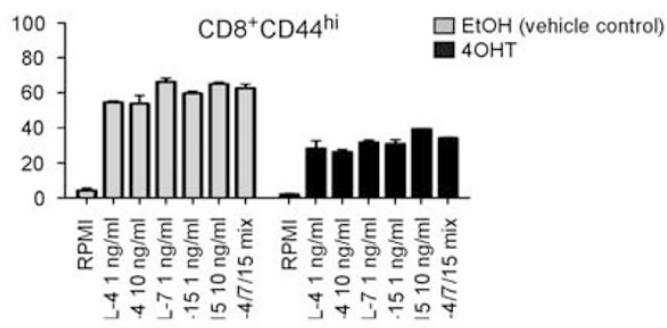

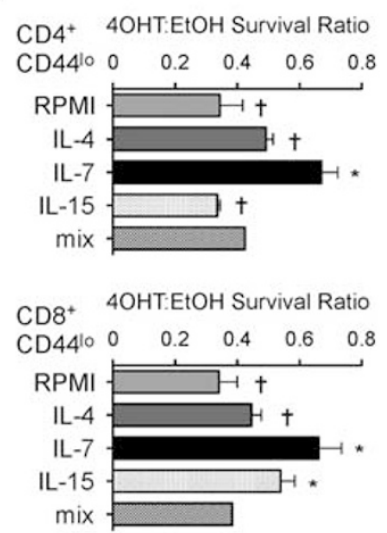

e

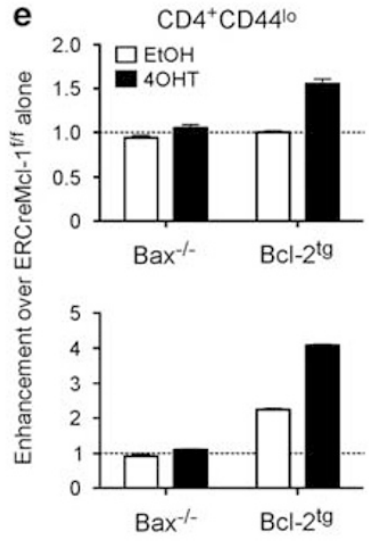

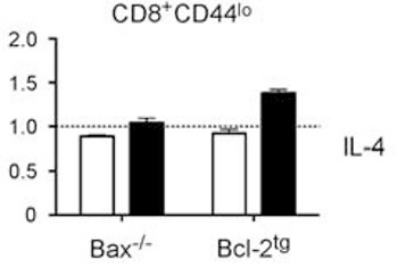

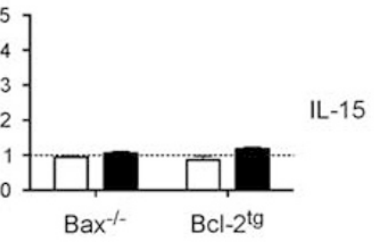

d

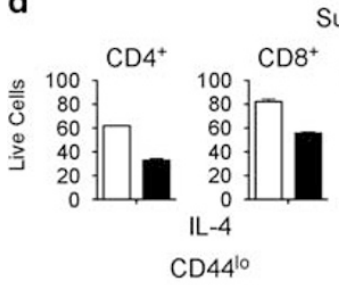

Survival of $\mathrm{MCl}-1 / 1 / \mathrm{ERCreBak}^{-1-}$ cells

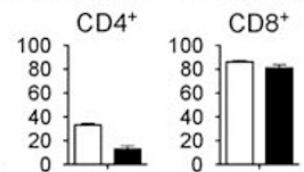

IL-15

$\mathrm{CD} 44^{10}$

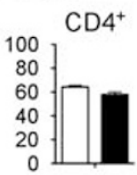

201120

IL-15

CD44hi

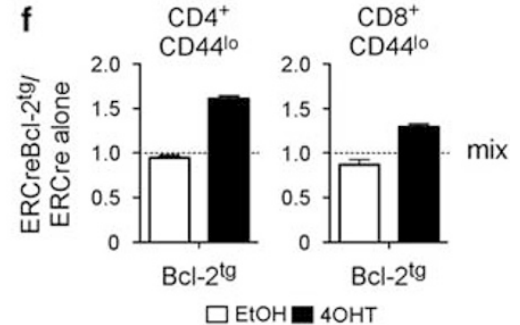

Figure 5 IL-4, IL-7, and IL-15 differentially modulate the T-cell requirement for Mcl-1. (a and b) Percent surviving cells after 3-day culture of CD44 ${ }^{\mathrm{lo}}$ (a) and CD44 ${ }^{\text {hi }}(\mathbf{b})$ cells in IL-4 $(1$ and $10 \mathrm{ng} / \mathrm{ml})$, IL-7 $(1 \mathrm{ng} / \mathrm{ml})$, IL-15 (1 and $10 \mathrm{ng} / \mathrm{ml})$, or a mix of all three cytokines $(1 \mathrm{ng} / \mathrm{ml}$ each). Data are the mean + S.D. of triplicate wells from a single experiment and are representative of two independent experiments in which all conditions were tested simultaneously. (c) $4 \mathrm{OHT} / \mathrm{EtOH}$ survival ratios of $\mathrm{CD} 44^{10} \mathrm{Mcl}-{ }^{\mathrm{t} / \mathrm{E}} \mathrm{ERCre}$ cells after $3-$ day culture in the presence of different cytokines. Data are mean ratios + S.E.M. of $2-5$ experiments. ${ }^{*} P<0.05$ versus ratio in RPMI. ${ }^{\dagger} P<0.05$ versus ratio in IL-7. (d) Survival

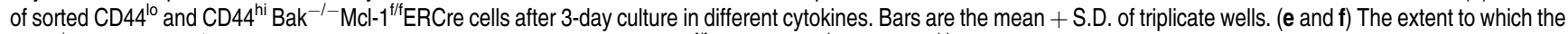
$\mathrm{Bax}^{-1-}(\mathbf{e})$ and Bcl-2 $2^{\mathrm{tg}}$ (e and f) backgrounds enhance the survival of Mcl-1 ${ }^{\mathrm{t} / \mathrm{E}} \mathrm{ERCre} \mathrm{CD} 44^{\mathrm{lo}}$ and CD44 ${ }^{\mathrm{hi}}$ cells in IL-4 or IL-15 (10 ng/ml; e) or in a mix of IL-4, IL-7, and IL-15

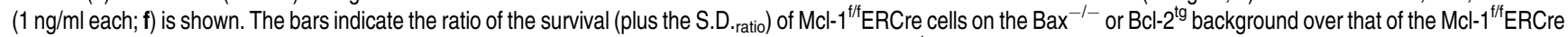
cells for a single experiment. A ratio of 1 (no enhancement) is indicated by a dotted line. The $\mathrm{Bcl}-2^{\text {tg }}$ data are representative of two independent experiments

modest extent (increase of $\sim 20 \%$ ) by western blotting (Figure 6c). We examined the expression of Bak and Bax by western blotting (day 1 was selected because of the low cell survival by day 3 in some conditions). Bak levels were slightly higher in pro-survival cytokines but were equivalent between cytokines. Bax expression was highest in IL-4, indicating another mechanism that could explain the increased sensitivity of cells in IL-4 to Mcl-1 deletion.

However, because of the surprising induction of Bim by prosurvival cytokines, the relative induction of Bim (normalized to RPMI) was measured by flow cytometry in CD $44^{\text {lo }}$ and CD $44^{\text {hi }}$ cells. In all T-cell subsets, IL-4, IL-7, and IL-15 induced Bim, but IL-4 resulted in the highest level of induction (Figure $6 \mathrm{~d}$ ). The induction of Bim was greater in CD44 ${ }^{\text {hi }}$ cells than in CD44 ${ }^{\text {lo }}$ cells. The induction of Bcl-2 in CD4 ${ }^{+}$cells illustrates the difference in responsiveness to $\mathrm{IL}-15$ between $\mathrm{CD} 4{ }^{+} \mathrm{CD} 44^{\mathrm{lo}}$ and $\mathrm{CD} 4{ }^{+} \mathrm{CD} 44^{\mathrm{hi}}$ cells (Figure $6 \mathrm{~d}$, bottom right). Interestingly, IL-4 induced $\mathrm{Bcl}-2$ to equal levels in CD $44{ }^{\text {hi }} \mathrm{CD} 4{ }^{+}$and CD $44^{\mathrm{lo}} \mathrm{CD} 4{ }^{+}$cells $(2.8$-fold and 2.7 -fold, respectively), but CD44 ${ }^{\text {hi }}$ cells induced higher levels of Bim than CD44 ${ }^{\text {lo }}$ cells (4.2-fold versus 2.8 -fold). The increased $\mathrm{Bim} / \mathrm{Bcl}-2$ induction ratio could be the reason why 

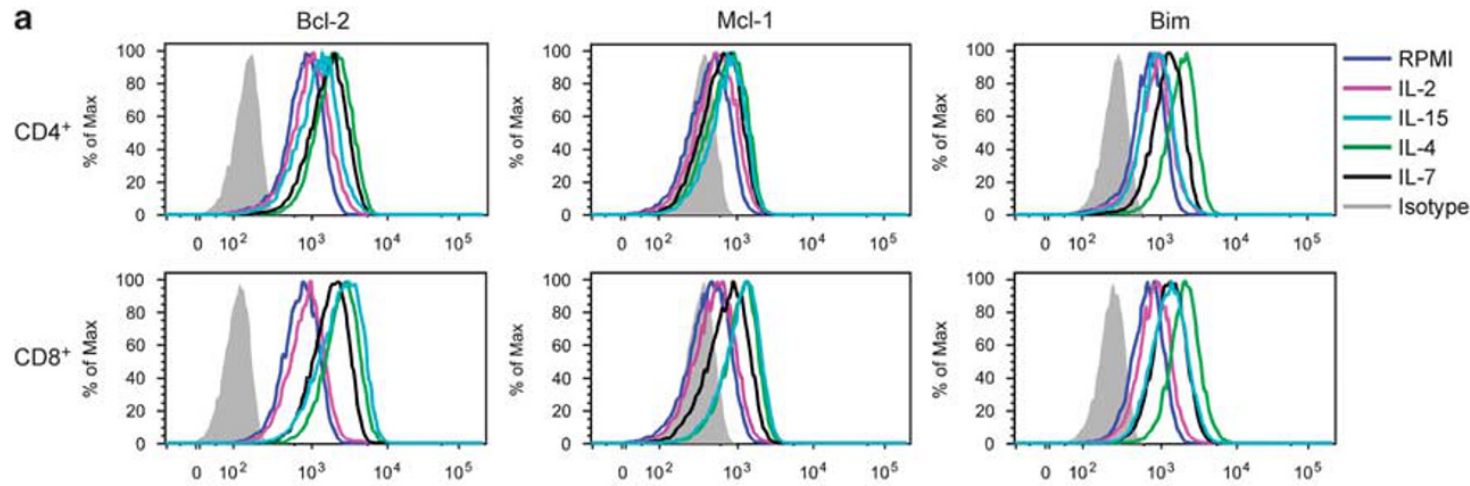

b

\begin{tabular}{|c|cccccc|}
\hline & \multicolumn{2}{|c}{ Mcl-1 } & \multicolumn{2}{c|}{ Bcl-2 } & \multicolumn{2}{c|}{ Bim } \\
\hline & $C D 4$ & $C D 8$ & $C D 4$ & CD8 & CD4 & CD8 \\
RPMI & 544 & 534 & 889 & 811 & 702 & 682 \\
IL-2 & 679 & 688 & 1082 & 972 & 881 & 828 \\
IL-4 & 967 & 1374 & 2197 & 2853 & 1881 & 2661 \\
IL-7 & 792 & 945 & 1793 & 1948 & 1272 & 1397 \\
IL-15 & 812 & 1228 & 1384 & 2827 & 961 & 1433 \\
\hline Isotype & 324 & 328 & 155 & 128 & 266 & 257 \\
\hline
\end{tabular}

C
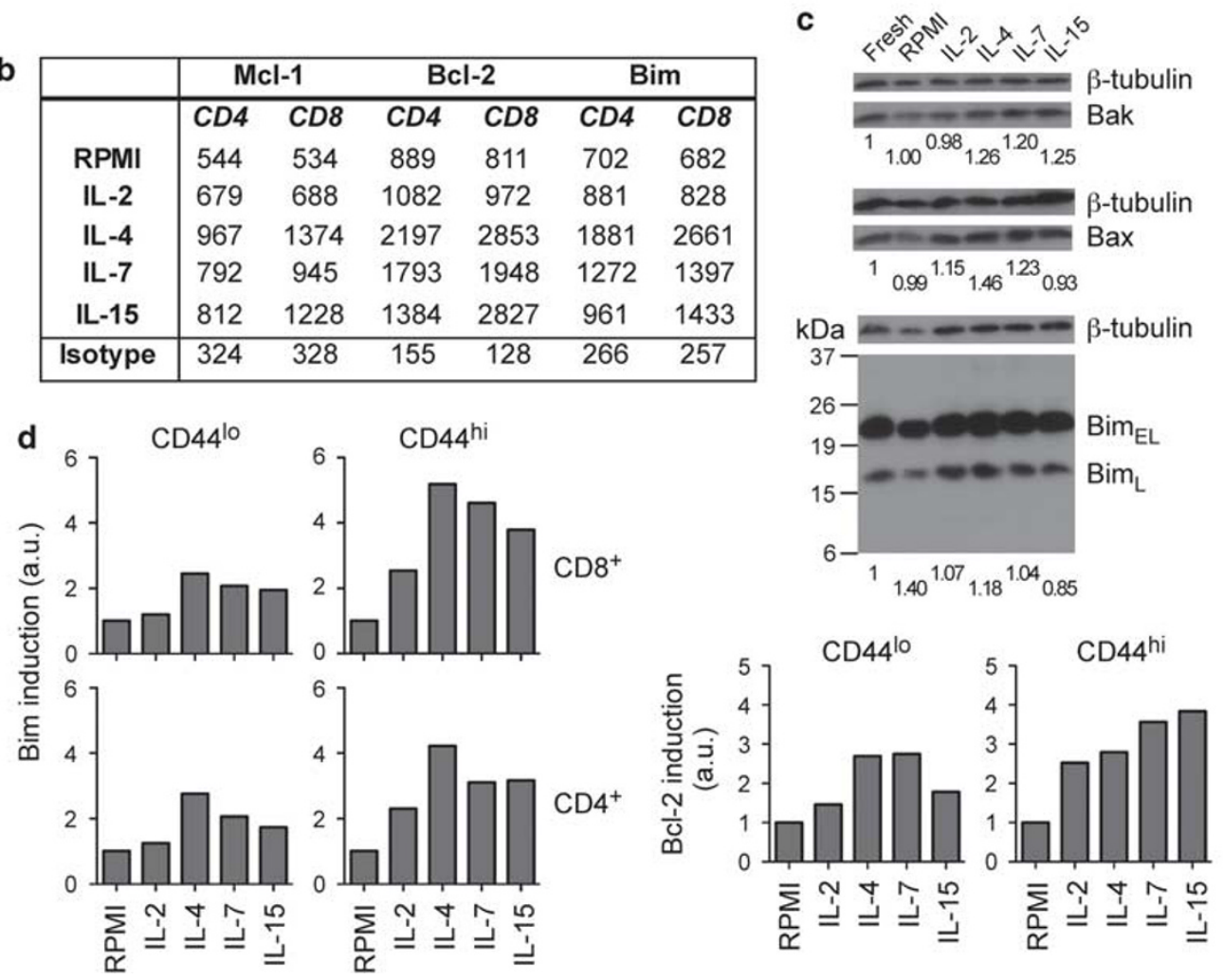

Figure 6 Regulation of Bcl-2-family protein expression by $\gamma \mathrm{c}$ cytokines. (a) Histograms of intracellular staining for Bcl-2, Mcl-1, and Bim on day 3. Cell populations were first gated on live cells by FSC and SSC, then on the CD44 $4^{\text {low }}$ population within the CD4 ${ }^{+}$and CD8 ${ }^{+}$T-cell gates. The shaded histogram is the isotype control. Data are representative of 1-2 experiments. (b) Mean fluorescence intensity (MFI) of Mcl-1, Bcl-2, and Bim staining. The mean of duplicate wells in each condition from a single experiment is shown, and the isotype control MFI was averaged from all of the conditions. (c) Western blot of Bak, Bax, and Bim expression in T cells cultured with cytokines for $22 \mathrm{~h}$. The corresponding loading control ( $\beta$-tubulin) for each blot is shown. The estimated relative intensities of Bak, Bax, and Bim, normalized to loading controls, were calculated as described in Materials and methods, and are shown underneath each blot. Lane 1 ('Fresh' $T$ cells) was arbitrarily defined as 1, and the number indicates the intensity relative to Lane 1. For Bim, the combined intensity for the Bim $\mathrm{EL}_{\mathrm{L}}$ and Bim $\mathrm{L}_{\mathrm{L}}$ isoforms was used. (d) The induction of Bim (left) and Bcl-2 (right) is compared between the different conditions in different T-cell subsets. The bars indicate the mean of two experiments in which the MFIs of duplicate wells were averaged and divided by the MFI of one isotype control well before normalizing to the value for RPMI. For Bcl-2, only CD4 ${ }^{+}$cells are shown to demonstrate the difference in responsiveness to IL-15 between CD44 ${ }^{10}$ and CD44 ${ }^{\text {hi }}$ cells

$\mathrm{CD} 4^{+} \mathrm{CD} 44^{\mathrm{hi}}$ cells had a more limited survival response to IL-4 than CD4 ${ }^{+}$CD $44^{\text {lo }}$ cells (Figure 5).

\section{Discussion}

Our data indicate that Mcl-1 has roles in multiple pathways: cytokine-dependent and cytokine-independent. A model for Mcl-1 activity in peripheral T cells is presented in Supplementary Figure S3. IL-4, IL-7, and IL-15 promote survival by upregulating $\mathrm{Mcl}-1$ and $\mathrm{Bcl}-2$ (indicated by arrows). With IL-7/IL-15 and sufficient Bcl-2, the critical role for Mcl-1 is to inhibit Bak (solid line), a biochemical function of Mcl-1 but not $\mathrm{Bcl}-2{ }^{35}$ This is consistent with our previous observations in the thymus, ${ }^{19}$ a cytokine-rich environment. Inhibiting Bim is not a critical function of Mcl-1 in the presence of IL-7 or IL-15 (in responding cells), likely due to the induction of sufficient $\mathrm{Bcl}-2$ to neutralize Bim. Bax inhibition is not a major function of $\mathrm{Mcl}-1$ in the presence of cytokines, but it is not clear whether 
Bax is kept inactive by direct inhibition by $\mathrm{Bcl}-2$ or by a lack of activating factors, leading to the retention of Bax in an inactive conformation or location.

Although IL-4 upregulated anti-apoptotic proteins to a similar level as IL-7 and IL-15, IL-4 induced higher levels of Bax and Bim. Bim induction by IL-4 shifts the dominant role of $\mathrm{Mcl}-1$ toward its shared role with Bcl-2. T cells in IL-4 were more sensitive to $\mathrm{Mcl}-1$ deletion, and did not exhibit the same pattern of rescue by the different genotypes as cells in IL-7/ IL-15. The enhanced upregulation of Bim is, to our knowledge, a novel function of IL-4 for which the biological reason and mechanism are unknown. STAT6, a molecule downstream of IL-4, but not IL-7 or IL-15, is dispensable for the pro-survival effect of $\mathrm{IL}-4$, but remains a candidate mechanism for the enhanced upregulation of Bim. ${ }^{2,31}$

Mcl-1 and $\mathrm{Bcl}-2$ share a role in protecting cells under conditions in which cytokines are scarce or absent, as evidenced by the partial rescue of Mcl-1-deficient cells by $\mathrm{Bcl}-2$ overexpression. Deficiency in Bim and, to a lesser extent, Bax partially rescued Mcl-1-deficient cell survival in RPMI. Therefore, Bim is a central mediator of the $\mathrm{Mcl}-1 / \mathrm{Bcl}-2$ shared pathway during cytokine withdrawal (Supplementary Figure S3), and the cytokine withdrawal-induced apoptotic pathway occurs preferentially but not exclusively through Bax. As the rescue of cytokine-starved cell survival by Bim deficiency did not equal that of Bcl-2 overexpression, other BH3-only proteins may promote apoptosis during cytokine withdrawal. Additionally, Bcl-2 overexpression did not fully rescue the survival of $\mathrm{Mcl}-1$-deficient cells under cytokine withdrawal, implying that $\mathrm{Mcl}-1$ also has a separate, specific role. Although Bak deficiency did not rescue under these conditions, Mcl-1 could still inhibit Bak (indicated by the dotted line in Supplementary Figure S3). The activation of Bim, which induces apoptosis through Bax, could mask the effect of Bak deficiency. To address this possibility, Bak and Bim must be simultaneously neutralized, perhaps in combination with other BH3-only proteins.

Our data indicate that IL-7, IL-15, and IL-4 all promote T-cell survival but differentially regulate $\mathrm{Bcl}-2$-family protein expression and the role of $\mathrm{Mcl}-1$. By examining the effects of different cytokines individually and together, we demonstrated how subtle differences in the cellular response to these similar cytokines affect T-cell survival by shifting the balance between the different roles of Mcl-1, specifically its role in antagonizing Bak and its shared role with Bcl-2 antagonizing Bim/Bax. Because of the increased upregulation of Bim by IL-4, T cells cultured with a mix of IL-4, IL-7, and IL-15 relied more heavily on the $\mathrm{Mcl}-1 / \mathrm{Bcl}-2$ shared pathway of survival than T cells in IL-7 or IL-15 alone, which relied on the inhibition of Bak.

Consistent with our results, a recent study noted expression of Bim in vivo in response to IL-7 and IL-15 (IL-4 not tested). ${ }^{36}$ This group demonstrated that expression of sufficient $\mathrm{Bcl}-2$ to neutralize the Bim is critical in effector/memory T-cell survival. ${ }^{36}$ As Mcl-1 is also expressed in effector and memory $\mathrm{T}$ cells, ${ }^{18}$ the specific activity of $\mathrm{Mcl}-1$ likely influences the effective balance of $\mathrm{Bcl}-2$ and $\mathrm{Bim}$ in these cells. The balance between the specific and shared functions of $\mathrm{Mcl}-1 / \mathrm{Bcl}-2$ may be critically important for regulating memory. Depending on the identity and concentration of cytokines present, $\mathrm{Mcl}-1$ will be more or less necessary to enhance Bcl-2 activity. As IL-4, which is produced during a Th2-polarized immune response, skews the primary role of $\mathrm{Mcl}-1$ toward inhibiting the Bim/Bax pathway, the susceptibility of T-cell subsets to apoptosis in Th1 versus Th2 conditions should be closely examined. As methods of detection continue to improve, it will be important to determine the precise local concentrations of cytokines in different niches, such as in circulation, or within lymphoid organs. Combined with our data, this will allow a better understanding of the processes that regulate cell survival in vivo.

In addition to the implications of our data on normal T-cell biology, the role of $\mathrm{Mcl}-1$ and the skewing of the apoptotic pathway by different cytokines could potentially be important in tumor biology. The Bcl-2-family proteins are frequently disregulated during oncogenesis, including that of the lymphoid system. The drug ABT-737, a synthetic inhibitor of $\mathrm{Bcl}-2$, $\mathrm{Bcl}-\mathrm{x}_{\mathrm{L}}$, and $\mathrm{Bcl}-\mathrm{w}$, is a potent antitumor agent. ${ }^{37} \mathrm{As} \mathrm{ABT}-737$ does not inhibit $\mathrm{Mcl}-1$, tumor cell resistance to ABT-737 correlates with $\mathrm{Mcl}-1$ levels. ${ }^{38,39}$ Intriguingly, factors such as cytokines may influence the extent to which tumor cells depend on the $\mathrm{Mcl}-1 / \mathrm{Bcl}-2$ shared versus unique pathway of survival. Although tumor immunity is typically associated with cytotoxic T-cell responses, the skewing of the apoptotic pathway toward the shared Bim/Bax pathway by IL-4 has interesting implications on how a Th2 response or IL-4 alone might indirectly promote tumor cell death. It is possible that this pathway could be manipulated therapeutically to enhance the efficacy of apoptotic drugs, such as ABT-737, that preferentially trigger the Bak or the Bim/Bax apoptotic pathway.

\section{Materials and Methods}

Mice. Mcl-1/f mice were generated as described previously and were backcrossed at least seven generations onto the $\mathrm{C} 56 \mathrm{BL} / 6$ strain background. ${ }^{40}$ The in vitro deletion of $\mathrm{Mcl}-1$ was achieved using the inducible knockout system in which ERCre is expressed from the Rosa26 gene locus. ${ }^{23} \mathrm{Bak}^{-1-}, \mathrm{Bax}^{-1-}$, and $\mathrm{Bim}^{-1-}$ mice were obtained from the Jackson Laboratory (Bar Harbor, ME, USA). $\mathrm{Bcl}-2^{\text {tg }}$ mice ${ }^{27}$ were provided previously by Dr. Motonari Kondo. Mice were maintained in specific pathogen-free conditions, and were utilized under protocols approved by the Duke University Institutional Animal Care and Use Committee.

Antibodies, cytokines, and other reagents. The antibodies used for sorting and surface staining for flow cytometry (against CD4, CD8, CD44, and TCR $\beta$ ) were obtained from Biolegend (San Diego, CA, USA). Rabbit anti-Bak, -Bax, -Bim, and - $\beta$-tubulin, as well as the horseradish peroxidase (HRP)-conjugated anti-rabbit antibody were from Cell Signaling Technology (Danvers, MA, USA). Rabbit anti-Mcl-1 was from Rockland Immunochemicals (Gilbertsville, PA, USA). The whole rabbit lgG isotype control and phycoerythrin (PE)-anti-rabbit IgG were from Jackson Immunoresearch (West Grove, PA, USA). The PE-conjugated Bcl-2 staining kit was obtained from BD Biosciences (San Jose, CA, USA). Murine IL-7, IL-4, and IL-15 were purchased from Peprotech (Rocky Hill, NJ, USA), and were dissolved according to the manufacturer's instructions. Cytokines were then diluted to $1000 \times$ stocks in medium (RPMI) and stored at $-80^{\circ} \mathrm{C}$ until use. Recombinant hIL-2 was obtained from the Duke University Pharmacy (Durham, NC, USA) and was diluted to a stock concentration of $10^{5}$ units $(\mathrm{U}) / \mathrm{ml}$ in medium and stored at $4^{\circ} \mathrm{C}$. $4 \mathrm{OHT}$ was obtained from Sigma (St. Louis, MO, USA), and was dissolved in $100 \%$ $\mathrm{EtOH}$ to a stock concentration of $500 \mu \mathrm{M}$. Propidium iodide (PI) was obtained from Sigma and was dissolved in phosphate-buffered saline (PBS) to a $500 \times$ stock concentration of $1 \mathrm{mg} / \mathrm{ml}$. All the media and its related solutions were from Invitrogen (Carlsbad, CA, USA)

Total splenocyte cultures and deletion of Mcl-1. Spleens were smashed and filtered through a nylon mesh to make a single-cell suspension in 
PBS. Red blood cells (RBCs) were lysed using ACK buffer for 1-2 min at room temperature, and the remaining cells were washed, counted, and resuspended in complete RPMI $(+10 \%$ fetal bovine serum (FBS) and $1 \times$ non-essential amino acids, L-glutamine, and penicillin/streptomycin) to a concentration of $2-4 \times 10^{6} \mathrm{cell} / \mathrm{s} / \mathrm{ml}$. Although the cell concentrations used varied slightly between different experiments, the cell concentrations of the different samples were kept constant within each experiment. A total of $100 \mu \mathrm{l}$ of cells was plated in triplicate onto 96-well Corning Costar plates with an equal volume of complete RPMI containing $4 \mathrm{OHT}$ or EtOH and cytokines as appropriate (final cell concentration was $\left.1-2 \times 10^{6} \mathrm{cell} / \mathrm{s} / \mathrm{ml}\right)$. $4 \mathrm{OHT}$ was used at a final concentration of $100 \mathrm{nM}$, and the $\mathrm{EtOH}$ vehicle control was prepared by adding an equivalent volume of $100 \% \mathrm{EtOH}$ to the control medium. The final concentration of IL-7 was $1 \mathrm{ng} / \mathrm{ml}$, the concentration of hIL-2 was $100 \mathrm{U} / \mathrm{ml}$, and the concentrations of IL-15 and IL-4 were both $10 \mathrm{ng} / \mathrm{ml}$, unless otherwise indicated in the figure. Cells were cultured in a $5 \% \mathrm{CO}_{2}, 37^{\circ} \mathrm{C}$ humidified atmosphere for 1,3 , or 5 days before analysis. Unless otherwise indicated, the data shown are from a 3-day culture of the cells.

Sorting of CD44 ${ }^{\mathrm{hi}}$ and CD44 ${ }^{\mathrm{lo}}$ cells. For experiments using sorted T cells, splenocytes as well as mesenteric and inguinal lymph nodes were collected, and RBCs were lysed as described above. Cells were resuspended in 2\% FBS in PBS for T-cell enrichment before sorting. T cells were enriched using the EasySep T-Cell Enrichment Kit (Stem Cell Technologies, Vancouver, BC, Canada), following the manufacturer's instructions. Cells were surface stained and sorted into CD44high (CD44 $\left.{ }^{\mathrm{hi}}\right)$ and CD44-low (CD44 ${ }^{\mathrm{lo}}$ ) populations on a FACSDiva (BD Biosciences) or MoFlo (Beckman Coulter, Miami, FL, USA) cell sorter. To increase the plating density of sorted cells, $\mathrm{CD} 4^{+}$and $\mathrm{CD}{ }^{+}$cells were cultured together within the $\mathrm{CD} 44^{\mathrm{hi}}$ and $\mathrm{CD} 44^{\mathrm{lo}}$ populations. Cells were cultured as described above, except with cell concentrations of $0.1-1 \times 10^{6} \mathrm{cell} / \mathrm{s} / \mathrm{ml}$.

Flow cytometry and measurement of cell survival. Cells were transferred into a U-bottom 96-well plate, centrifuged, and resuspended in $25 \%$ $24 \mathrm{G} 2$ hybridoma supernatant (Fc block) in 2\% FBS. After a 10-15 min blocking step, cells were stained with antibodies to surface molecules for $15-30 \mathrm{~min}$. Cells were washed with $2 \% \mathrm{FBS}$, and were resuspended in $2 \% \mathrm{FBS}$ containing PI at $2 \mu \mathrm{g} / \mathrm{ml}$. Cells were kept on ice throughout the staining, and until analysis on a FACSCanto cytometer (BD Biosciences). Flow cytometry data were analyzed using FlowJo software (Tree Star Inc., Ashland, OR, USA). Events were initially gated on live and dead cells (and 'debris' was removed) based on forward and side scatter (FSC and SSC). Then $\mathrm{CD} 4^{+} \mathrm{TCR} \beta^{+}$and $\mathrm{CD} 8^{+} \mathrm{TCR} \beta^{+}$populations were gated (in some cases with the addition of the marker CD44), and the percentage of cells in each population that was negative for PI staining was determined.

Intracellular staining for Mcl-1, Bcl-2, and Bim. T cells were enriched as described above using the EasySep T Cell Enrichment Kit (Stem Cell Technologies), following the manufacturer's instructions. Cells were plated in a 96-well plate at a density of $1-2 \times 10^{6} \mathrm{cell} / \mathrm{s} / \mathrm{ml}$ in the presence of IL-2 $(100 \mathrm{U} / \mathrm{ml})$, IL-4 $(10 \mathrm{ng} / \mathrm{ml}), \mathrm{IL}-7(1 \mathrm{ng} / \mathrm{ml})$, or IL-15 $(10 \mathrm{ng} / \mathrm{ml})$ or without cytokine. After 3 days in culture, cells were surface-stained as described above, fixed in $1 \%$ paraformaldehyde on ice for $20 \mathrm{~min}$, and stored at $4^{\circ} \mathrm{C}$ overnight. Cells were permeabilized with $0.1 \%$ saponin in $2 \%$ FBS. For the Mcl-1 and Bim stains, the permeabilization buffer contained $5 \%$ donkey serum and 10\% $24 \mathrm{G} 2$ supernatant. After permeabilization, cells were centrifuged and resuspended in $90 \mu \mathrm{l}$ of the same buffer. PE-anti-Bcl-2 and the corresponding isotype control were added at $10 \mu \mathrm{l} / \mathrm{stain}$ as per the manufacturer's recommendation. Stock solutions of anti-Mcl-1 $(0.1 \mathrm{mg} / \mathrm{ml}$ in $50 \%$ glycerol in PBS) and anti-Bim $(0.234 \mathrm{mg} / \mathrm{ml}$ in $50 \%$ glycerol) were diluted so as to add $10 \mu \mathrm{l}$ of the diluted antibody solution to yield a final dilution of $1: 100$ (Mcl-1) or 1:200 (Bim). For the isotype controls, stock solutions of rabbit lgG were prepared to equivalent concentrations in $50 \%$ glycerol in PBS, and were diluted and added to the appropriate wells accordingly. For each condition, one well was stained with each isotype control and duplicate wells were used for each of the specific antibody stains. After primary antibody staining, cells were washed in $0.1 \%$ saponin two times, and cells for the Mcl-1 and Bim stains, as well as the isotype controls, were incubated in PE-anti-rabbit lgG $(1 \mu / /$ well) in $0.1 \%$ saponin. Cells were washed two times and were analyzed immediately using a FACSCanto cytometer (BD Biosciences). For the subsequent analysis, only those cells in the 'live' gate by forward and side scatter were used.

To assess Mcl-1 deletion in the different genotypes by measuring Mcl-1 protein levels, splenocytes were cultured under the same conditions used to assess survival. The Mcl-1 staining was performed as described above. The cell-survival data for each experiment in which Mcl-1 staining was performed were confirmed to represent a typical experiment for that genotype. To determine whether the doubleknockout cells rescued the survival of Mcl-1-deficient cells by selecting for undeleted cells, the Mcl-1 protein levels were compared between knockout and wild-type cells for Bak, Bim, and Bak with and without the deletion of Mcl-1. To do this, the mean fluorescence intensities (MFIs) of duplicate Mcl-1-stained wells were averaged, and divided by the MFI of the isotype control well for each condition and cell type to obtain a value for Mcl-1 expression. Then, the ratio of the Mcl-1 expression level in knockout (Bak, Bim, or Bax) cells to that in wild-type cells was calculated to determine if any increase in expression over wild-type could be observed in the knockout.

Western blotting. Enriched T cells were prepared as described and were plated onto six-well plates at a density of $2 \times 10^{6} \mathrm{celll} / \mathrm{ml}\left(6 \mathrm{ml}, 12 \times 10^{6} \mathrm{cells} / \mathrm{well}\right)$ in the presence or absence of cytokines. After 1 day ( $24 \mathrm{~h})$, the cells were collected into $15-\mathrm{ml}$ conical tubes, washed with PBS, and resuspended in $150 \mu \mathrm{l}$ of SDS sample buffer $(50 \mathrm{mM}$ Tris $\mathrm{HCl}, \mathrm{pH} 6.8$ and $2 \%$ SDS) containing $20 \mathrm{mM}$ freshly added dithiothreitol (DTT). Cells were lysed on ice for $30 \mathrm{~min}$, then $30 \mu \mathrm{l}$ of $6 \times$ sample buffer containing bromophenol blue and glycerol (at final concentrations of $0.1 \%$ and $10 \%$, respectively) was added, and samples were boiled for $5 \mathrm{~min}$. Protein lysate aliquots were stored at $-80^{\circ} \mathrm{C}$ until use. For 'fresh' $\mathrm{T}$ cells, an equal number of cells were lysed immediately after T-cell enrichment, and the sample was prepared and stored as described. Protein samples were subjected to sodium dodecyl sulfate-polyacrylamide gel electrophoresis (SDSPAGE) and were transferred to a polyvinylidene fluoride (PVDF) membrane (ImmobilonP; Millipore, Billerica, MA, USA). To allow simultaneous staining of Bak, Bax, or Bim and the loading control ( $\beta$-tubulin), the membranes were cut at the 37$\mathrm{kDa}$ marker, and the top half was used for $\beta$-tubulin, while the bottom half was used for the Bcl-2 family protein. The membranes were blocked with $5 \%$ milk in PBS-T (PBS containing $0.2 \%$ Tween-20) at room temperature with gentle shaking for $45 \mathrm{~min}$, followed by incubation in primary antibodies (all used at 1:1000 in 3\% bovine serum albumin (BSA) in PBS-T) for $1-1.5 \mathrm{~h}$ also at room temperature with gentle shaking. After washing in PBS-T $(3 \times 10 \mathrm{~min})$, the HRP-conjugated anti-rabbit secondary antibody was added (1:5000 in 3\% BSA in PBS-T), and the membranes were gently shaken at room temperature for $1 \mathrm{~h}$. The membranes were washed $(3 \times 10 \mathrm{~min}$ in PBS-T) and incubated in the SuperSignal West Pico Substrate (Pierce/Thermo Scientific, Rockford, IL, USA) for $5 \mathrm{~min}$ before the signal was detected by exposure to film.

Image analysis for western blotting. To estimate the relative intensities of the Bak, Bax, and Bim bands, corrected by the $\beta$-tubulin loading control bands, the gel analysis tools of the ImageJ software (http://rsbweb.nih.gov/ij/) were used. For each blot, a histogram was plotted for the signal in each lane, and the peak corresponding to the band was defined by drawing a line across the bottom of the peak based on the signal in the background region. The area under the peak was calculated relative to Lane 1 (fresh T cells, arbitrarily set to 1). To correct for slight differences in protein loading, the relative intensity of Bak, Bax, or Bim was divided by the relative intensity of the corresponding $\beta$-tubulin band to yield a loadingcorrected estimated intensity of Bak, Bax, or Bim relative to Lane 1.

Statistical analyses. Additional data analysis and the graphing of data were performed using Prism (GraphPad Software, Inc., La Jolla, CA, USA). The mean percent survival of triplicate wells in each condition was determined for each experiment. The figures from representative individual experiments depict the mean percent survival plus the standard deviation (S.D.) of triplicate wells. To determine the Mcl-1-dependent survival ratio, the mean survival of the wells cultured in $4 \mathrm{OHT}$ was divided by the mean survival of the corresponding wells in EtOH control medium (labeled EtOH in figures). The S.D. of the $4 \mathrm{OHT} / \mathrm{EtOH}$ ratio for individual experiments with triplicate wells was calculated using the equation

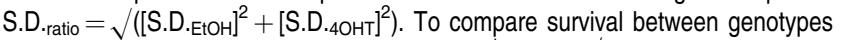
(as in Figure $5 \mathrm{e}$ ) the ratio of the survival of $\mathrm{Bcl}-2^{\text {tg }}$ or $\mathrm{Bax}^{-1-}$ cells to that of $\mathrm{Bcl}-2 /$ Bax wild-type cells from the same experiment (all on the Mcl- $1^{\text {t/f }} \mathrm{ERCre}$ background) was calculated for each condition, and the S.D. .ratio was used. To combine multiple experiments, the $4 \mathrm{OHT} / \mathrm{EtOH}$ survival ratios of the individual experiments were averaged, and the mean plus standard error of the mean (S.E.M.) are depicted in the figures. To assess statistical significance, an unpaired Student's $t$ test was used, and $P$-values less than 0.05 were considered to be significant. For some figures (as indicated in the legends), a 'graded' indication of significance is depicted using the following symbols: ${ }^{*} P<0.05 ;{ }^{* \star} P<0.01$; and ${ }^{* \star} P<0.001$. 


\section{Conflict of Interest}

The authors declare no conflict of interest.

Acknowledgements. This work was supported by NIH grant no.Al074754.

1. Surh CD, Sprent J. Homeostasis of naive and memory T cells. Immunity 2008; 29 848-862.

2. Rochman $Y$, Spolski R, Leonard WJ. New insights into the regulation of $T$ cells by gamma(c) family cytokines. Nat Rev Immunol 2009; 9: 480-490.

3. Khaled AR, Durum SK. Lymphocide: cytokines and the control of lymphoid homeostasis. Nat Rev Immunol 2002; 2: 817-830.

4. Wei MC, Zong WX, Cheng EH, Lindsten T, Panoutsakopoulou V, Ross AJ et al. Pro-apoptotic BAX and BAK: a requisite gateway to mitochondrial dysfunction and death. Science 2001; 292: 727-730.

5. Kuwana T, Mackey MR, Perkins G, Ellisman MH, Latterich M, Schneiter R et al. Bid, Bax and lipids cooperate to form supramolecular openings in the outer mitochondria membrane. Cell 2002; 111: 331-342.

6. Cheng EH, Wei MC, Weiler S, Flavell RA, Mak TW, Lindsten T et al. BCL-2, BCL-X(L) sequester $\mathrm{BH} 3$ domain-only molecules preventing $\mathrm{BAX}$ - and $\mathrm{BAK}$-mediated mitochondrial apoptosis. Mol Cell 2001; 8: 705-711.

7. Letai A, Bassik MC, Walensky LD, Sorcinelli MD, Weiler S, Korsmeyer SJ. Distinct BH3 domains either sensitize or activate mitochondrial apoptosis, serving as prototype cancer therapeutics. Cancer cell 2002; 2: 183-192.

8. Kuwana T, Bouchier-Hayes L, Chipuk JE, Bonzon C, Sullivan BA, Green DR et al. BH3 domains of $\mathrm{BH} 3-$ only proteins differentially regulate Bax-mediated mitochondria membrane permeabilization both directly and indirectly. Mol Cell 2005; 17: 525-535.

9. Chen L, Willis SN, Wei A, Smith BJ, Fletcher JI, Hinds MG et al. Differential targeting of prosurvival $\mathrm{Bcl}-2$ proteins by their $\mathrm{BH}$ 3-only ligands allows complementary apoptotic function. Mol Cell 2005; 17: 393-403.

10. Kim H, Rafiuddin-Shah M, Tu HC, Jeffers JR, Zambetti GP, Hsieh JJ et al. Hierarchica regulation of mitochondrion-dependent apoptosis by BCL-2 subfamilies. Nat cell biol 2006; 8: $1348-1358$

11. Willis SN, Fletcher JI, Kaufmann T, van Delft MF, Chen L, Czabotar PE et al. Apoptosis initiated when BH3 ligands engage multiple Bcl-2 homologs, not Bax or Bak. Science 2007; 315: 856-859.

12. Lindsten T, Ross AJ, King A, Zong WX, Rathmell JC, Shiels HA et al. The combined functions of pro-apoptotic Bcl-2 family members bak and bax are essential for normal development of multiple tissues. Mol Cell 2000; 6: 1389-1399.

13. Rathmell JC, Lindsten T, Zong WX, Cinalli RM, Thompson CB. Deficiency in Bak and Bax perturbs thymic selection and lymphoid homeostasis. Nat Immunol 2002; 3: 932-939.

14. Veis DJ, Sorenson CM, Shutter JR, Korsmeyer SJ. Bcl-2-deficient mice demonstrate fulminant lymphoid apoptosis, polycystic kidneys, and hypopigmented hair. Cell 1993; 75 : 229-240.

15. Nakayama K, Nakayama K, Negishi I, Kuida K, Sawa H, Loh DY. Targeted disruption of $\mathrm{Bcl}-2$ alpha beta in mice: occurrence of gray hair, polycystic kidney disease, and lymphocytopenia. Proc Natl Acad Sci U S A 1994; 91: 3700-3704.

16. Nakayama K, Nakayama K, Negishi I, Kuida K, Shinkai Y, Louie MC et al. Disappearance of the lymphoid system in Bcl-2 homozygous mutant chimeric mice. Science 1993; 261 1584-1588.

17. Opferman JT, Letai A, Beard C, Sorcinelli MD, Ong CC, Korsmeyer SJ. Development and maintenance of B and T lymphocytes requires anti-apoptotic MCL-1. Nature 2003; 426 671-676

18. Dzhagalov I, Dunkle A, He YW. The anti-apoptotic Bcl-2 family member Mcl-1 promotes T lymphocyte survival at multiple stages. J Immunol 2008; 181: 521-528.

19. Dunkle A, Dzhagalov I, He YW. Mcl-1 promotes survival of thymocytes by inhibition of Bak in a pathway separate from Bcl-2. Cell Death Differ 2010; 17: 994-1002.

20. Bouillet P, Purton JF, Godfrey DI, Zhang LC, Coultas L, Puthalakath $\mathrm{H}$ et al. BH3-only Bcl-2 family member Bim is required for apoptosis of auto-reactive thymocytes. Nature 2002 415: 922-926.

21. Bouillet $\mathrm{P}$, Cory S, Zhang LC, Strasser A, Adams JM. Degenerative disorders caused by Bcl-2 deficiency prevented by loss of its BH3-only antagonist Bim. Dev Cell 2001; 1 : 645-653.

22. Wojciechowski S, Tripathi P, Bourdeau T, Acero L, Grimes HL, Katz JD et al. Bim/Bcl-2 balance is critical for maintaining naive and memory T-cell homeostasis. J Exp Med 2007; 204: 1665-1675.

23. Shapiro-Shelef M, Lin Kl, Savitsky D, Liao J, Calame K. Blimp-1 is required for maintenance of long-lived plasma cells in the bone marrow. J Exp Med 2005; 202: $1471-1476$

24. Khaled AR, Li WQ, Huang J, Fry TJ, Khaled AS, Mackall CL et al. Bax deficiency partially corrects interleukin-7 receptor [alpha] deficiency. Immunity 2002; 17: 561-573.

25. Akashi $\mathrm{K}$, Kondo $\mathrm{M}$, von Freeden-Jeffry $\mathrm{U}$, Murray $\mathrm{R}$, Weissman IL. Bcl-2 rescues T lymphopoiesis in interleukin-7 receptor-deficient mice. Cell 1997; 89: 1033-1041.

26. Maraskovsky E, O'Reilly LA, Teepe M, Corcoran LM, Peschon JJ, Strasser A. Bcl-2 can rescue T lymphocyte development in interleukin-7 receptor-deficient mice but not in mutant rag-1 ${ }^{-1-}$ mice. Cell 1997; 89: 1011-1019.

27. Domen J, Gandy KL, Weissman IL. Systemic overexpression of BCL-2 in the hematopoietic system protects transgenic mice from the consequences of lethal irradiation. Blood 1998; 91: 2272-2282.

28. Bouillet P, Metcalf D, Huang DC, Tarlinton DM, Kay TW, Kontgen F et al. Pro-apoptotic $\mathrm{Bcl}-2$ relative Bim required for certain apoptotic responses, leukocyte homeostasis, and to preclude autoimmunity. Science 1999; 286: 1735-1738

29. Dijkers PF, Medema RH, Lammers J-WJ, Koenderman L, Coffer PJ. Expression of the pro-apoptotic Bcl-2 family member Bim is regulated by the forkhead transcription factor FKHR-L1. Curr Biol 2000; 10: 1201-1204.

30. Rathmell JC, Farkash EA, Gao W, Thompson CB. IL-7 enhances the survival and maintains the size of naive T cells. J Immunol 2001; 167: 6869-6876.

31. Vella A, Teague TK, Ihle J, Kappler J, Marrack P. Interleukin 4 (IL-4) or IL-7 prevents the death of resting T cells: stat6 is probably not required for the effect of IL-4. J Exp Med 1997; 186: $325-330$.

32. Zhang X, Sun S, Hwang I, Tough DF, Sprent J. Potent and selective stimulation of memory-phenotype CD8+ T cells in vivo by IL-15. Immunity 1998; 8: 591-599.

33. Lodolce JP, Boone DL, Chai S, Swain RE, Dassopoulos T, Trettin S et al. IL-15 receptor maintains lymphoid homeostasis by supporting lymphocyte homing and proliferation. Immunity 1998; 9: 669-676.

34. Berard M, Brandt $\mathrm{K}$, Bulfone-Paus S, Tough DF. IL-15 promotes the survival of naive and memory phenotype CD8+ T cells. J Immunol 2003; 170: 5018-5026.

35. Willis SN, Chen L, Dewson G, Wei A, Naik E, Fletcher Jl et al. Pro-apoptotic Bak is sequestered by $\mathrm{Mcl}-1$ and $\mathrm{Bcl}-\mathrm{xL}$, but not $\mathrm{Bcl}-2$, until displaced by $\mathrm{BH} 3-$ only proteins. Genes Dev 2005; 19: 1294-1305.

36. Kurtulus S, Tripathi P, Moreno-Fernandez ME, Sholl A, Katz JD, Grimes HL et al. Bcl-2 allows effector and memory CD8+ T cells to tolerate higher expression of Bim. J Immunol 2011; 186: 5729-5737.

37. Oltersdorf T, Elmore SW, Shoemaker AR, Armstrong RC, Augeri DJ, Belli BA et al. An inhibitor of Bcl-2 family proteins induces regression of solid tumours. Nature 2005; 435 : $677-681$

38. Konopleva M, Contractor R, Tsao T, Samudio I, Ruvolo PP, Kitada S et al. Mechanisms of apoptosis sensitivity and resistance to the $\mathrm{BH} 3$ mimetic ABT-737 in acute myeloid leukemia. Cancer cell 2006; 10: 375-388

39. van Delft MF, Wei AH, Mason KD, Vandenberg CJ, Chen L, Czabotar PE et al. The BH3 mimetic ABT-737 targets selective Bcl-2 proteins and efficiently induces apoptosis via $\mathrm{Bak} / \mathrm{Bax}$ if $\mathrm{Mcl}-1$ is neutralized. Cancer cell 2006; 10: 389-399.

40. Dzhagalov I, St. John A, He Y-W. The anti-apoptotic protein Mcl-1 is essential for the survival of neutrophils but not macrophages. Blood 2007; 109: 1620-1626.

(c)

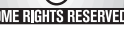
licensed under the Creative Commons Attribution-Noncommercial-No Derivative Works 3.0 Unported License. To view a copy of this license, visit http://creativecommons.org/licenses/by-nc-nd/3.0/

\section{Supplementary Information accompanies the paper on Cell Death and Disease website (http://www.nature.com/cddis)}

